\title{
Drugs and Drug Candidates from Marine Sources: An Assessment of the Current "State of Play"
}

Authors

Affiliation
David J. Newman, Gordon M. Cragg

NIH Special Volunteers, Natural Products Branch, National Cancer Institute, Frederick, MD, USA
Key words

- marine-sourced drugs

- clinical trials

- cancer

- HIV

\section{Abstract \\ $\nabla$}

The potential of the marine environment to produce candidate compounds (structures) as leads to, or even direct drugs from, has been actively discussed for the last 50 or so years. Over this time frame, several compounds have led to drugs, usually in the area of cancer (due to funding sour- ces). This review is designed to show where there have been successes, but also to show that in a number of disease areas, there are structures originally isolated from marine invertebrates and free-living microbes that have potential, but will need to be "adopted" by pharmaceutical houses in order to maximize their potential. received August 20, 2015

revised Nov. 30, 2015

accepted January 5, 2016

Bibliography

Dol http://dx.doi.org/

10.1055/s-0042-101353

Published online Februaray 18 , 2016

Planta Med 2016; 82: 775-789

(c) Georg Thieme Verlag KG

Stuttgart · New York .

ISSN 0032-0943

\section{Correspondence}

\section{Dr. David J. Newman}

664 Crestwood Road

Wayne, PA 19087

USA

Phone: + 16109719784

Fax: + 16109712526

djnewman664@verizon.net

\section{Introduction}

\section{$\nabla$}

The oceans of the world cover roughly $71 \%$ of the planet with a median depth of $>3000 \mathrm{~m}$ and a mean depth of $3800 \mathrm{~m}$. Of this enormous expanse, less than $5 \%$ of the deep sea has been explored in any way and less than $0.01 \%$ of the deep sea floor has been sampled in detail [1]. What is also of significance is that of the 36 animal phyla identified taxonomically, 34 are found in the marine environment [2] and, of these, approximately half are only found in marine environments. Of the remainder, approximate half are both marine and terrestrial (though predominately marine) and only one, the phylum Onychophora (the velvet worms), is exclusively terrestrial.

Although organisms had been recovered from relatively shallow depths in the $1800 \mathrm{~s}$ and had been seen for many centuries on coral reefs and beaches, not until the Challenger expedition in the 1872-1876 time frame, and then the Galathea expedition in 1950-1952 where live animals from the Philippines Trench at $10190 \mathrm{~m}$ [3] were recovered, was it realized that with the possible exception of the anoxic zones in the Black Sea, living animals could be found at all depths. The reason for using "possible" as a modifier in the sentence above is that the formaniferan tube worms found at "black smokers" are in anoxic environments and utilize microbes of the sulfur cycle to survive and grow.
Who first decided to investigate the marine environment as a source of medicaments is unknown, but both Japanese and Chinese herbals contained various mixtures that were used as part of traditional medicine, and certainly the toxic properties of marine-derived products were well known centuries ago, with perhaps the best known example being the puffer fish (Fugu) in Japanese cuisine (though see the comments on tetrodotoxin later in this review). From a historical perspective, "Tyrian Purple", a dyestuff from a Mediterranean mollusk used in Roman times, actually has significant activity in some cancers and was used as a part of traditional Chinese medicine (TCM) for the treatment of leukemia. It is only recently that it was realized that the active chemical compounds (marine sourced and plant sourced, respectively) were of the same basic chemical class and may well be of microbial origin in both cases. This article will deal with the potential of the marine (aquatic) environment and its organisms, as leads to agents that have been approved for use against diseases of man (and in one case, for use in agriculture), by the relevant agencies of governments worldwide. These will be drugs, not food supplements or functional foods, etc. We will discuss those that are approved, are in clinical trials, and show where the molecules came from, directly, modified by synthesis, or even total synthesis based on a marine-sourced compound. In one case, a compound that had been in clinical trials 


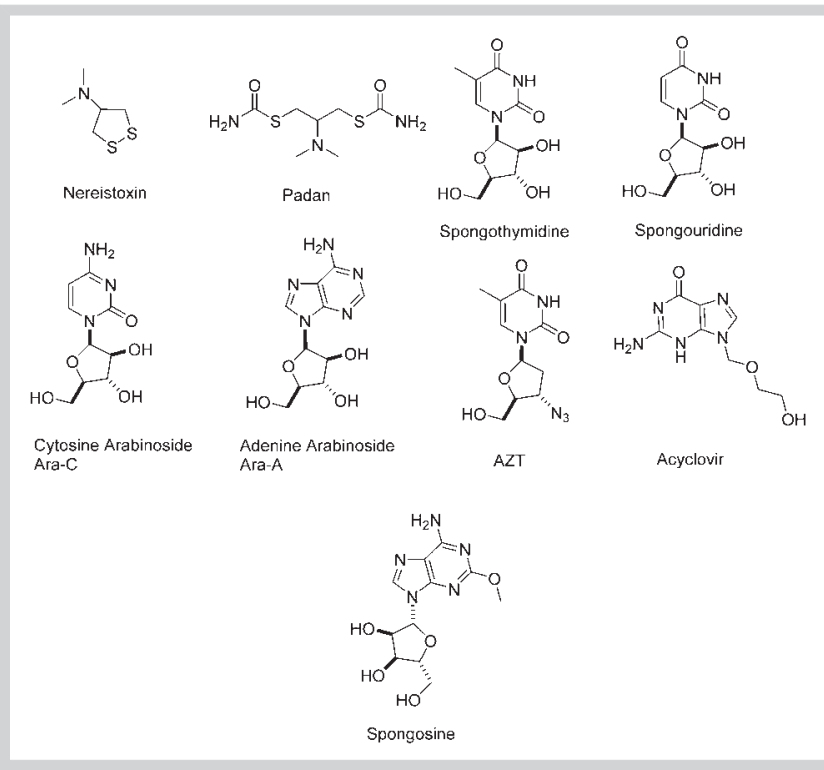

Fig. 1 Early agents from marine sources and their subsequent derivatives.

as an antitumor agent has now gained a new "lease on life" as a potential treatment for other unrelated diseases.

What will, however, become obvious as the stories unfold is that the original organism from which the compound was isolated (usually a marine invertebrate) may or may not be the actual producer of the metabolite(s) of interest. Where the true producer is known, it will be identified, but in a significant number of cases, the evidence is still circumstantial, though in other cases, the organism is directly identifiable.

\section{The Early Record}

$\nabla$

Though found in both marine and aquatic environments ranging from the Sea of Japan to Lake Victoria in Central Africa, one can argue that one of the first generally used "marine" invertebratesourced secondary metabolites was the toxin known as nereistoxin ( Fig. 1) from the flatworm Lumbrineris brevicirra (also named Lumbriconeris heteropoda). This worm had probably been used for centuries by fishermen to stun fish within the lake, thus permitting them to harvest their catches rather easily. It might almost be called a "chemical equivalent" of the dynamite fishing system used by fishermen in countries such as the Philippines and other areas of SE Asia. In addition, Japanese fishermen had known for years that the flatworm had anti-insecticidal properties, as it killed carnivorous insects when they landed on it.

In 1934, Nitta isolated the active principle in the flatworm, with a structure being proposed by Okaichi and Hashimoto in 1962 and confirmed by total synthesis as reported by Hagiwara et al. in 1965 [4]. This compound was shown to be an acetylcholine antagonist and over the next few years, insecticides were developed from the base structure, with a close analogue, $\operatorname{Padan}^{\circledR}$ (๑ Fig. 1), being marketed by Takeda in 1967.

There had been sporadic reports from at least two millennia ago of pharmacologically active agents being isolated and identified from marine organisms; but, it was not until the middle of the 20th Century that any form of systematic investigation occurred. Thus, in the early 1960 s to early 1970 s, academic groups in the
USA, and pharmaceutical company-linked organizations such as the Roche Institute for Marine Pharmacology in Australia, reported their findings in a variety of formats. The best source for information on these and earlier studies is probably the 1976 review by Ruggieri, which should be consulted by interested readers [5].

\section{Arabinose-containing nucleosides}

One may argue, and the authors (in a news interview in the early $1990 \mathrm{~s}$ ) and another have done so [6,7], that the seminal discoveries, and thus the impetus for the investigation of marine biodiversity and the subsequent vision of marine-derived drugs on the market, can be traced to the identification by Bergmann in the early $1950 \mathrm{~s}$ of the arabinose-containing bioactive nucleosides spongothymidine and spongouridine ( $\bullet$ Fig. 1 ) from the Caribbean sponge Tethya crypta [8-10]. These discoveries overthrew the then current dogma; a nucleoside had to have either ribose or deoxyribose as the sugar moiety in order to demonstrate biological activity.

Thus, cytosine arabinoside (Ara-C, cytarabine, 0 Fig. 1 ), a very well-known and prescribed antitumor agent, though not originally found in such a marine environment as "Ara-C", can trace its chemical lineage back to the discovery of bioactive nucleosides that contained arabinose rather than ribose or deoxyribose. Though we were not the first to recognize the importance of such substitutions, since, as mentioned earlier, Suckling, in a review in a journal that was not well known [6], reported on the chemistry involved in the syntheses of these and other such arabinoselinked nucleosides with common or uncommon bases, we were perhaps the first to formally link the discoveries of the marinesourced natural arabinoses by the Bergmann group to the "design" of this agent. So, Ara-C can be legitimately considered to be a marine-derived agent, since without arabinose in place of deoxyribose or ribose, it would simply have been a normal component of nucleic acids.

As of the 15th of August 2015, there are 828 trials listed in the NIH (National Institutes of Health, Bethesda, Maryland, USA) clinical trials database, with 262 of them being open studies that are recruiting and covering a large number of cancers, ranging from Phase IV down to Phase I. In the corresponding European database, 127 clinical trials covering the same phases, but with some overlap, are listed, and in the World Health Organization database, just looking at Australasia, there are 17 open trials not duplicated in the other two databases. As with other well-known approved drugs, cytarabine is still in use, more than 40 years after its initial approval, with an interesting recent paper questioning the use of high-dose cytarabine therapy during remission in adults with acute myeloid leukemia [11].

Other closely related compounds such as adenine arabinoside (Ara-A; O Fig. 1), an antiviral compound synthesized and commercialized by Burroughs Wellcome (now Glaxo SmithKline), were based upon the arabinose substitution, but in contrast to Ara-C, this compound was later found in the Mediterranean gorgonian Eunicella cavolini [12], and thus could be considered a natural product, even though it was synthesized de novo before its discovery in the gorgonian. Similar reasoning related to unusual sugars and bioactivity led to investigations on the minimum size of sugar rings and the effect of other substitutions on the sugar ring(s); thus azidothymidine (AZT; $\bullet$ Fig. 1) and even acyclovir ( $\bullet$ Fig. 1 ) can be traced back to this initial discovery. Very recently, a group of investigators at the Scripps Institution of Oceanography reported that a strain of the Gram-negative bacte- 
rium, Vibrio harveyi, which was isolated from the sponge Tectitethya crypta (the current name for the sponge that Bergmann used in the $1950 \mathrm{~s}$ ), produced spongosine and spongothymidine (ه Fig. 1) amongst other nucleosides on fermentation [13]. Whether the microbe is the only producer has not been conclusively proven, there may be interplay between the microbe and the sponge host, but it is extremely suggestive as other related materials were obtained from other strains of the microbe, and a putative spg biosynthetic cluster was identified in the microbe's DNA.

\section{History}

$\nabla$

By the middle $1960 \mathrm{~s}$, the terrestrial "plant world" had been reasonably well explored for novel anticancer drug candidates and reported on by a number of groups, with agents such as the Vinca alkaloids first being reported as potential antitumor agents in the late 1950 s. Similarly, the terrestrial microbial world had been explored in a somewhat systematic fashion, from roughly the late $1940 \mathrm{~s}$, with success in both antibiotic and antitumor areas. A number of agents from microbial sources, or successors utilizing their pharmacophores, which are still in current clinical use, were first identified in the late 1950 s to early 1960 s, mainly in concert with industry. Good examples being the anthracyclines in cancer, penicillins, and cephalosporins and their thousands of "chemical offspring", all with a beta-lactam ring as antimicrobials, or the antimicrobial carbohydrate-based aminoglycosides, some of which have gained a "new lease on life" as molecular biology tools rather than antibiotics.

Although there had been a number of reports of biologically active agents from marine (and freshwater) environments ( $c f$ discussion on arabinosides above), predominately by academic researchers who received funding from either the National Institutes of Health $(\mathrm{NIH})$ component institutes or the National Science Foundation (NSF) for basic research, no systematic explorations had been performed of marine environments as sources of structural or direct leads to medicaments.

Starting in the early $1960 \mathrm{~s}$, the National Cancer Institute (NCI), the largest institute within the US government's NIH, expanded its horizons beyond the testing of synthetic compounds as experimental antitumor agents and began large-scale studies of natural products. Plant materials were collected and recollected when required (and if feasible) in conjunction with the United States Department of Agriculture (USDA). Microbial products were usually provided by pharmaceutical companies and small numbers of marine invertebrates were also obtained by purchase from commercial collectors.

These materials were then extracted by predominately academic groups, the extracts tested initially in whole animal models (mouse and rat tumors) and later in fast-growing mouse leukemia cell lines (P388 and L1210) by contractor laboratories to the US government, with "active materials" then being isolated and identified by the academic collaborators. At the same time, academic investigators, including those who were also acting as $\mathrm{NCI}$ collaborators/contractors, were also expanding their investigator-initiated grant applications (known as R01 grants) towards the marine environment, with the aim of collecting and utilizing marine invertebrates as sources of drug leads (marine biodiscovery).

\section{Approved Marine-Derived Antitumor Agents and (Chemically) Related Compounds $\nabla$}

As implied by the title of this section, if there are related compounds that entered clinical trials they will be discussed after the approved agent with notes as to their current status. Examples as discussed below include the MAb-linked agents involving dolastatin derivatives and molecules related to ET743.

\section{Dolastatin-derived approved agent (Adcetris ${ }^{\circledR}$ ) and related antibody-drug conjugates}

One of the two antitumor compounds that came from what might be considered the earliest systematic investigations of the marine environment for such agents, as distinct from finding activities for isolated compounds, was dolastatin 10 (๑ Fig. 2), one of a series of linear and cyclic peptides isolated from the herbivorous sea hare Dolabella auricularia. The extensive isolation/synthesis programs and then clinical trials in man over the next 20 plus years have been given in detail by two of the early coinvestigators and should be consulted for details if desired [14,15]. Subsequently, the dolastatins were shown to be produced not by the animal but by a cyanobacterium of the genus Symploca [16], though very recently this organism was renamed into the new genus Caldora and species penicillata [17].

None of the dolastatins, including dolastatin 10, progressed beyond Phase II clinical trials as the isolated compound, which was initially synthesized due to the very low levels found in the animal. A variety of later chemical variations also entered clinical trials. These included auristatin PE (trials under the names of soblidotin, TZT-1027, or YHI-201), cemadotin, and synthadotin (also known as tasidotin or ILX-651), but none proceeded beyond Phase I or early II levels.

However, due to the very high potency of two variations on auristatin, compounds later known as monomethylauristatin E [MMAE or vedotin ( Fig. 2)] and its phenylalanine variant, monomethylauristatin F [MMAF ( Fig. 2)], Seattle Genetics were able to link specific monoclonal antibodies to both of these "warheads", leading in 2011 to the approval of the antibody drug conjugate (ADC) Adcetris ${ }^{\circledR}$ ( Fig. 2). The vast amount of work required, first in optimizing vedotin-based warheads and then developing the linkers that couple the antibody to the compounds, was described by Doronina et al. in 2006 [18]. Some of these were designed to release the warhead (vedotin) by simple hydrolysis of a linker bond, whereas others require the enzymatic digestion of the antibody, releasing the warhead plus appendages.

Adcetris ${ }^{\circledR}$, also known as "cAC10-vcMMAE", consists of a human/ mouse monoclonal antibody linked to 8 valine-citrulline-MMAE molecules where the MAb was directed against the CD30 epitope expressed in leukemic cells. The agent was approved by the FDA in 2011 and subsequently approval was given in the EU late in 2012 and launched in the UK in early 2013, all for CD30 positive leukemias. Full explanations of the methodologies used and the utility of this agent against a variety of lymphomas were published in the 2010-2013 time frame and should be consulted by the interested reader [19-22].

In late 2013, the authors listed the extensive number of MMAE and MMAF antibody conjugates that were in clinical trials [23], and on checking the records approximately 20 months later, as expected, "trial attrition" has occurred, with the numbers now reduced to six MMAE-MAb compounds (four in Phase II and two in Phase I) with one MMAF-MAb in Phase I. In late 2014, Smaglo et al. published an excellent review on ADCs discussing others in 


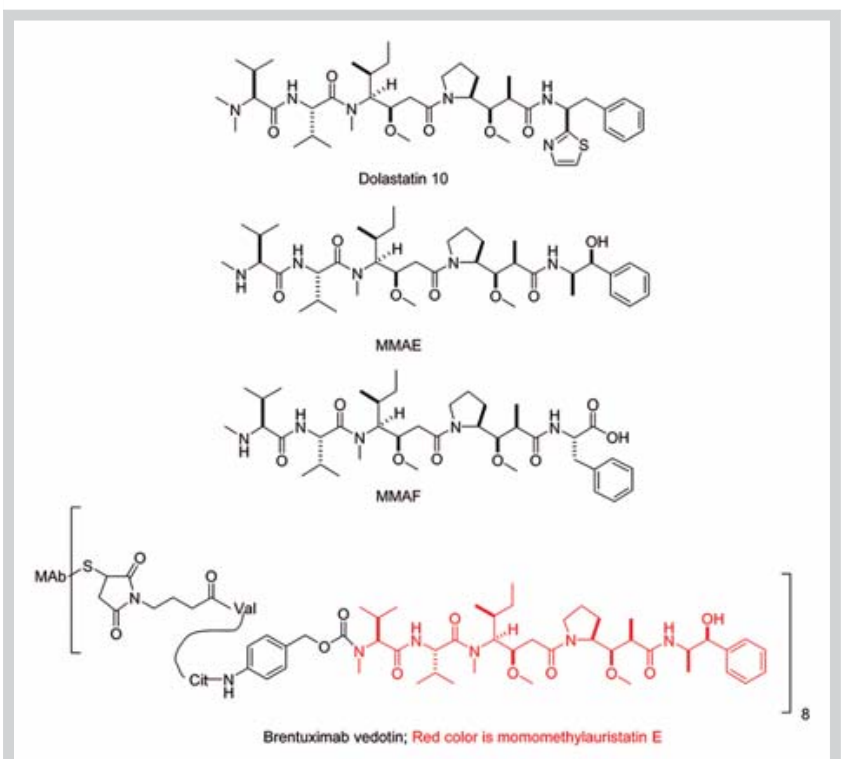

Fig. 2 Dolastatin-derived approved agent (Adcetris ${ }^{\circledR}$ ) and related antibody-drug. (Color figure available online only.)

addition to the MMAE/F series, which should be consulted for general and specific studies [24].

Currently (August 9th, 2015), the following agents utilizing MMAE/F as warheads are still in "active and recruiting" clinical trials and their status will be discussed in brief in the following section. Thus, as mentioned above, a considerable number of the molecules listed in the early 2014 Marine Drugs review [23] are not included as there are currently no trials falling under these criteria listed in any of the governmental databases. Since in the majority of cases results are published well after the trial(s) have finished, no update(s) is/are feasible at this stage as to why compounds were dropped from clinical trials.

\section{Glembatumumab vedotin (Phase II)}

In this combination, MMAE is linked to a fully human monoclonal antibody CR011 (an anti-CG56972) via the valine-citrulline dipeptide linker as in Adcetris $^{\circledR}$. It was initially targeted against patients with unresectable melanomas at stage III or IV who had failed one cytotoxic chemotherapy regimen, and was then expanded to include metastatic breast cancer as well. The combination has had a variety of names during its evolution including CDX-011, CR-011, and CR011-vcMMAE, so searching for data can be a trifle challenging.

The initial report of the use of this combination was given by investigators from CuraGen in 2006 [25], followed by a report of xenograft activity in 2007 from the same group [26]. The potential of the monoclonal's target in triple negative breast cancer was described in 2010 by Rose et al. [27], and the corresponding details in melanoma were described in 2012 by a group from the People's Republic of China [28]. Currently, three completed studies at the Phase I/II levels are reported in the NIH clinical trials database with a recent discussion on the management of metastatic breast cancer with this agent by Vaklavas and Forero [29]. There are reports of clinical activity in breast cancer patients [30, 31], and a report of clinical efficacy in advanced melanoma [32]. There is some dichotomy as to the clinical trial status of this compound, but using the clinical trials database from the NIH and the Celldex website (http://www.celldex.com/pipeline/ pipeline-overview.php), as of August 11th 2015, the compound is listed as being at Phase II with a new indication showing recurrent or refractory osteosarcoma (NCT02487979).

\section{Pinatuzumab vedotin; DCDT-2980 S (Phase II)}

This ADC from Genentech is a humanized IgG1 antibody directed against the CD22 epitope expressed in leukemias. The warhead is linked in a similar manner to that used in Adcetris ${ }^{\circledR}$, and releases monomethylauristatin $\mathrm{E}$ on protease cleavage. A modified safety protocol was used in the development of this agent, as the CD22 epitope is not expressed in rodents, so trials for safety were performed in cynomolgus monkeys, and demonstrated adequate safety in primates plus efficacy in xenografts [33]. Currently, there is one Phase II trial recruiting in the NIH clinical database (NCT01691898) and one duplicative record in the EU equivalent (www.clinicaltrialsregister.eu/ctr-search/search?query; EudraCT number 2011-004377-84). This trial is in non-Hodgkin's lymphoma, not solid tumors.

\section{Polatuzumab vedotin; DCDS-4501 A (Phase II)}

This is also a Genentech/Roche product, and is an ADC with monomethylauristatin $\mathrm{E}$ linked to an anti-CD79b monoclonal. It is currently in the same Phase II trial as DCDT-2980 S (NCT01691898) as an alternative treatment against non-Hodgkin's lymphoma, and is also in an ongoing Phase II trial (NCT02257567) against various lymphomas in a dose escalation study. In addition, there is a Phase I trial against B-cell non-Hodgkin's lymphoma (NCT 01992653 ). As with the Roche agent above (EudraCT number 2011-004377-84), no other trials are listed in the EU database.

\section{Lifastuzumab vedotin; DNIB-0600Aor RG-7599}

(Phase II/I)

This ADC is a humanized IgG1 monoclonal antibody directed against the NaPi2b epitope linked to valine-citrulline-monomethylauristatin E. There are three clinical trials shown on the $\mathrm{NIH}$ site. NCT01995188 is a Phase I trial against ovarian cancer, NCT01363947 is another Phase I trial directed against non-squamous non-small cell lung cancer and ovarian cancer, and the third, NCT01991210, is a Phase II trial against ovarian cancer, epithelial, tumors, peritoneal neoplasms, and malignant fallopian tube cancer. Two reports in abstract form have been published to date, one from the 2013 American Society for Clinical Oncology (ASCO) meeting [34], and one from the 2014 European Society for Medical Oncology (ESMO) meeting [35].

\section{DSTP-3086 S}

(RG-7450; thio-antiSTEAP1-MC-vc-PAB-MMAE; Phase I)

This is a Genentech (Roche) ADC using an antibody against a humanized anti-STEAP1 IgG1 antibody, which was modified via determination/modification of reactive thiols according to the patent application by Bhakta and Junutula [36], and then coupled to the standard valine-citrulline-linked MMAE. The antibody is directed against the six-transmembrane epithelial antigen of prostate 1 , hence the STEAP1 acronym, and was initially evaluated as the basic ADC with the vc-MMAE with an unmodified MAb and then the thio-modified antibody. The decision was made to proceed with the thio-modified version from the PK determinations [37,38]. Currently, there is one Phase I study recruiting patients with metastatic castration-resistant prostate cancer (NCT01283373) with preliminary reports showing some clinical responses given at the 2013 and 2014 ASCO Meetings [39, 40]. 
HuMab-TF-011-vcIMMAE

(HuMax-TF-ADC; TF-011-MMMAE; Phase I)

TF-011-vcMMAE is an ADC under clinical development by Genmab and Seattle Genetics for the treatment of solid tumors. It is composed of a human tissue factor (TF) specific antibody (TF011), linked to valine-citrulline-MMAE. This ADC is currently in a Phase I safety study against ovarian, cervical, endometrial, bladder, prostate, esophageal, and non-small cell lung cancers under trial number NCT02001623. The NIH website shows trials in the US and the EU (UK and Denmark, but there is no current record in the EudraCT database).

\section{GSK2857916 (J6M0-mcIMIMAF; Phase I)}

Currently, this ADC is the only MMAF-linked combination in clinical trials, and unlike the MMAE-based ADCs, this ADC uses the protease stable maleimidocaproyl (mc) linker technology as described by Doronina et al. in 2006 [18] rather than the more common protease cleavable valine-citrulline version.

As of the time of this writing, this ADC is in one clinical trial (NCT02064387), an open-label, dose escalation with sites in the USA, Canada, and the UK. The patients desired for this trial will have one of the following: relapsed/refractory multiple myeloma or other advanced hematologic malignancies that express B-cell maturation antigen (BCMA). This antigen is a member of the tumor necrosis factor receptor super-family (TNFRSF17), which is known to be selectively induced during plasma cell differentiation and is effectively absent on naive and memory B cells.

\section{ET743 [EMEA-Approved drug (Yondelis ${ }^{\circledR}$ )] and Related Compounds in Clinical Trials $\nabla$}

This compound could be considered the "poster child" for marine-derived antitumor agents. The reason is that currently it is the only molecule in use as an antitumor agent, identical to a compound originally isolated from Ecteinascidia turbinata. The evolution of this agent from the discovery, preclinical, and clinical development followed a tortuous path. It utilized materials from massive direct collections of the "producing" tunicate in the Caribbean and Mediterranean seas, in-sea and on land aquaculture, and finally, semi-synthesis from a precursor molecule, cyanosafracin B, obtained by fermentation of a marine-derived microorganism.

The initial reports of bioactivity in this organism in 1970 were first reported by Sigel et al. [41], which was then followed by the initial identification of the "ecteinascidin series" by Holt in his $\mathrm{PhD}$ thesis in 1986 [42]. Further work by the Rinehart group at the University of Illinois (Urbana Champaign, Illinois, USA) and the Wright group at Harbor Branch Oceanographic Institution (Fort Pierce, Florida, USA) led to the simultaneous publication in 1990 of the structure of ET743 and associated molecules $[43,44]$. ET743 was licensed to the Spanish company PharmaMar following the demise of the US biotech company SeaPharm in 1988, and the subsequent semisynthetic work on this compound was well described by the investigators at PharmaMar in 2009 [45], and as part of a discussion on the development of marine-sourced drug entities in 2012 [46]. Both of these reports demonstrated the power of semi-synthesis and optimization of processes to obtain active drug principles.

The molecule was approved in the European Union (EU) in 2007 for treatment of advanced soft tissue sarcoma (STS). Currently, it is approved in over 70 countries as monotherapy for STS and in a number of countries for treatment of recurrent platinum-sensitive ovarian cancer when coupled to liposomal doxorubicin. In 2009, the corresponding US FDA application for the STS treatment was withdrawn. However, in February 2015, it was accepted for priority review for STS in the USA following submission of a New Drug Application (NDA) in late November 2014.

The mechanism of action (and there may well be others) is related to the excision repair complex as described by Soares et al. in 2007 [47]. In 2014, D'Incalci et al. published an excellent short review on the current state of knowledge of the mechanism(s) of action, and they stated in that review that "trabectedin not only inhibits the growth of cancer cells but also affects the tumour microenvironment (TME) by limiting the numbers of macrophages and by inhibiting the production of macrophage products that eventually promote tumour growth" [48].

The commonalities and differences in the pharmacological response of trabectedin and its close relatives, zalypsis ${ }^{\circledR}$ and lurbinectedin (○ Fig. 3; vide infra), were discussed in 2013 with respect to their experimental effect upon the Fanconi anemia pathway. Martinez et al. [49] demonstrated that these three related agents inhibited the Fanconi anemia pathway in the cell lines tested, increasing their sensitivity to mitomycin C. This is in contrast to mitomycin $\mathrm{C}$ by itself, which in the same cell lines always activated that pathway. The authors suggested that as a result of these findings, these three agents might be useful clinically in "Fanconizing" cancer cells in order to gain sensitivity against other antitumor drugs.

The same year, Romano et al. $[50,51]$ reported that in in vitro and in vivo models, no relationship was found between the in vitro cytotoxic potency and in vivo antitumor activity in syngeneic mouse models, suggesting that there might well be a host response in these models. Also, the pharmacokinetics differ, even between the quite similar trabectedin and lurbinectedin in humans, and as expected due to the differences in structure, Zalypsis ${ }^{\circledast}$ has been shown to differ in pharmacokinetics in humans [52].

As of August 12th, 2015, there were 20 open studies found for ET743 in the NIH clinical trials database, five at Phase III, eight at Phase II, one at Phase I, and six that were not given a Phase designation, with cancer types covering breast, prostate, soft tissue sarcoma, and osteosarcoma, plus general carcinomas. Searching the corresponding EU Clinical Trials Register (database), 26 trials were listed from 2006 to 2015 with eight being Phase II trials not found on the NIH site. These listings demonstrate that once a compound has been approved for treatment of one type of cancer, it will be placed in clinical trials for many others, either individually or as part of a new drug regimen.

A discussion of the evidence and probabilities of ET743 and its congeners being produced by as yet uncultured microbes associated with the source tunicate was published by Giddings and Newman in 2013 [53]. That this is in fact the case was confirmed by the very recent publication by the Sherman group at the University of Michigan identifying the microbe genetically [54]. This is the second paper using isolation and genetic analysis of an as yet uncultured microbe to prove the presence of the biosynthetic cluster(s) of the secondary metabolites found in the marine invertebrate in the microbe, with the first being the seminal paper by the Piel group published in Nature in early 2014 [55]. 

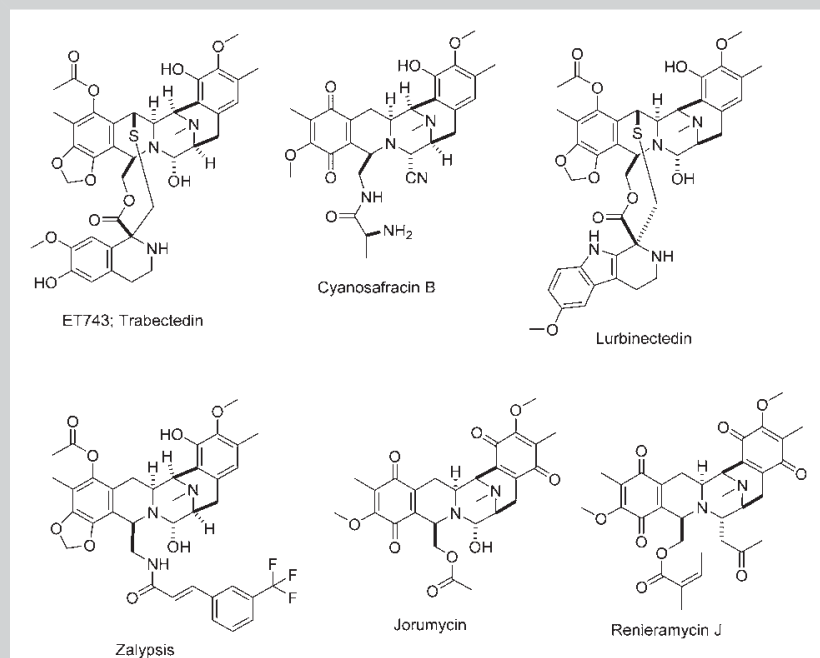

Fig. 3 ET743 and related compounds.

\section{Lurbectedin (PM01183; Phases I-III)}

This compound is another variation on the basic structure of the dimeric isoquinoline alkaloids such as ET743, but with a tetrahydro- $\beta$-carboline moiety instead of the tetrahydroisoquinoline present in ring C, and like ET743, it binds in the DNA minor groove [56]. The compound had different pharmacokinetics in patients to ET743 and attenuated nuclear excision repair (NER). It also had synergy with platinum-based agents in vitro, which suggested a potential treatment regimen, as it also demonstrated activity against platinum-resistant cell lines [57]. As of August 12th, 2015, there are 10 open clinical trials on the NIH site, one at Phase III, four at Phase II, and five at Phase I, plus one Phase II (in Spain) on the EU site that is not duplicated on the NIH site.

\section{PM-10450 (Zalypsis ${ }^{\circledR}$; Phase II)}

This compound is yet another variation on the basic structure of the dimeric isoquinoline alkaloids, and was derived from the structure of jorumycin, a compound isolated from the skin and mucin of the nudibranch Joruna funebris [58], and renieramycin $\mathrm{J}$ (○ Fig. 3) from a species of the marine sponge Netropsia sp. [59]. Zalypsis ${ }^{\circledR}$ was synthesized by workers at PharmaMar using techniques similar to those described for the ET743 synthesis from safracin B [60]. The molecular pharmacology of this agent was described by Leal et al. in 2009 and, surprisingly, though it has a close resemblance to ET743, it does not activate the DNA damage checkpoint response [61].

There is a dichotomy between the PhamaMar web site and the EudraCT (EU) web site as to status of the compound. On the PharmaMar site (www.PharmaMar.com; accessed August 12th, 2015), this compound is not listed as being in any trials. However, on the EU site, there is still a listing under 2009-016054-40 of an ongoing Phase II trial in Spain. No open trials, however, are shown on the $\mathrm{NIH}$ site, so it is feasible that this compound is being dropped.

\section{Eribulin, (Halaven $\left.{ }^{\circledR} ; \mathrm{E}-7389\right)$, a halichondrin B derivative} This agent is a wholly synthetic molecule modeled on a little over half of the structure of the naturally occurring antitubulin compound halichondrin B ( $\odot$ Fig. 4 ), specifically the ring plus a small "carbon tail". This molecule came from a tour-de-force based

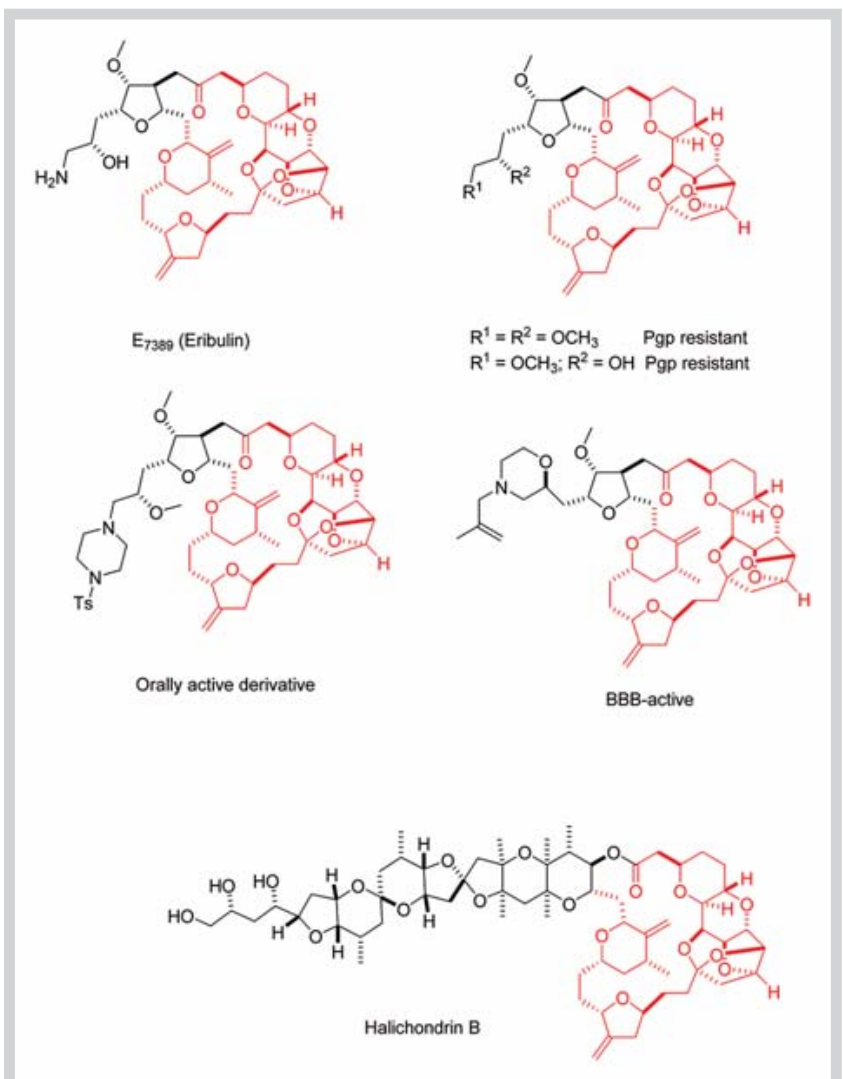

Fig. 4 Eribulin (Halaven ${ }^{\circledR}$; E-7389) and modifications, halichondrin B. (Color figure available online only.)

upon the synthetic method for halichondrin B first reported by Kishi's group in 1992 [62]. During this synthesis and the investigation by scientists at the Eisai Research Institute (ERI) in Woburn, Massachusetts of the synthetic intermediates, Kishi and ERI scientists realized that the active part of the molecule resided in the macrolide ring (approx MW of 600) and not in the "tail" (the remaining $400+$ of the overall $1000+\mathrm{MW}$ ). Chemists at the ERI working very closely with the Kishi group synthesized over 200 molecules and, in conjunction with the Developmental Therapeutics Program (DTP) at NCI, they chose the modified truncated macrocyclic ketone (eribulin, E-7389; $\odot$ Fig. 4) as the candidate compound when compared in in vitro and in vivo studies to pure halichondrin B (obtained by DTP in conjunction with New Zealand scientists). Much fuller details of the synthetic and base biological information were published by the leaders of the synthetic studies in 2005 [63]. This review article should be read by the interested reader for fuller details of the evolution of this compound through early 2005.

Eribulin, as with the "natural product parent", is a tubulin interactive agent with very potent activity at the nanomolar level in in vitro studies. In 2005, Jordan et al. [64] demonstrated that suppression of microtubule growth was the primary antimitotic mechanism of eribulin, with differential effects due to the concentration when studied in MCF7 cells. At low concentrations, eribulin potently inhibited microtubule dynamics, resulting in a prolonged arrest of mitosis and inducing apoptosis, whereas at tenfold the $\mathrm{IC}_{50}$ value (or higher concentrations), it induced depolymerization $[64,65]$. Later work demonstrated eribulin's interaction with centromere dynamics [66]. 
That the actual interaction of eribulin with tubulin may be even more complex than was originally thought is shown by the data reported by Jordan's group in a 2010 paper [67]. Using ${ }^{3} \mathrm{H}$-eribulin, they found a very high affinity site $\left(K_{d} 400 \pm 200 \mathrm{nM}\right)$ on $25 \%$ of the tubulin mass (which might be the $\alpha \beta_{\text {III }}$ tubulin dimer), with a stoichiometry of $0.26 \pm 0.12$ moles of eribulin per tubulin dimer. Another high affinity site $\left(K_{d} 3.5 \pm 0.6 \mu \mathrm{M}\right.$; stoichiometry of $14.7 \pm$ 1.3 eribulin: tubulin dimer) was also identified together with a low affinity site $\left(K_{d} \sim 46 \pm 28 \mu \mathrm{M}\right.$; stoichiometry of $1.3 \pm 0.4$ saturable sites per tubulin dimer).

The binding isotherm from these results is highly complex, which might well be due to the competition for eribulin between soluble tubulin and microtubules, though there is photo- and electron-micrographic evidence in the paper, and in earlier ones from the same group, for binding to the plus end of microtubules and preferentially to $\beta$-tubulin. As mentioned in the paper [67], further experimentation will be required to explain these complex results.

In 2007, a review by Wang et al. [68] gave extensive coverage of the patent routes to eribulin, with some duplication of the work presented in the 2005 review by Yu et al. [63]. Then, in 2009, three publications from the Kishi group detailed improved methods for the synthesis of eribulin. Though these papers were written from an academic perspective, they considered the relative costs of production [69-71]. Following on the synthetic stories, two excellent reviews were written in early 2009 by the Phillips' group at the University of Colorado, covering the published syntheses by many groups of halichondrin $B$, norhalichondrin $B$, and eribulin $[72,73]$. These papers were then followed by three articles in 2013 that covered the process chemistry involved in producing multi hundred gram quantities under CGMP conditions [74-76], and the overall story by the leader of the initial chemical synthesis [77].

In 2011, three papers were published by the ERI group demonstrating that with only a relatively minor change to the "tail" of the molecule ( $\odot$ Fig. 4 ), significant pharmacological effects could be demonstrated. If the diol that is the eribulin precursor was changed to the dimethoxy substituent, or the terminal amino group was changed to a methoxy group, the compounds now had a much lower propensity for inducing P-glycoprotein susceptibility. Both compounds were potent in vivo and had a reduction of approximately 30 -fold in terms of being substrates for P-glycoprotein compared to eribulin [78].

The ERI chemists then demonstrated that by substituting a substituted 1,4-diazacyclohexanyl group for the terminal amino group in eribulin and changing the sidechain hydroxyl group to a methoxyl, the compound ( $\odot$ Fig. 4 ) demonstrated oral activity in a subcutaneous LOX melanoma model and maintained a low susceptibility to P-glycoprotein induction [79]. Since there are very few treatments for brain tumors, the group then modified the base eribulin molecule by ring closure at the "tail" to give a morpholino derivative ( $\odot$ Fig. 4). This molecule was subtly different from the orally active compound referred to above, and demonstrated intravenous in vivo activity in an orthotopic murine model of a human glioblastoma [80].

Although it took 25 years from the original report in 1985 on halichondrin B until late 2010 to approve eribulin, the interplay of academic, industrial, and government laboratories in three continents led to this novel agent, the most complex drug molecule yet produced by total synthesis. What is of great importance is that without the structure of the halichondrin $\mathrm{B}$ from a Japanese sponge and the subsequent purification of halichondrin B by NZ

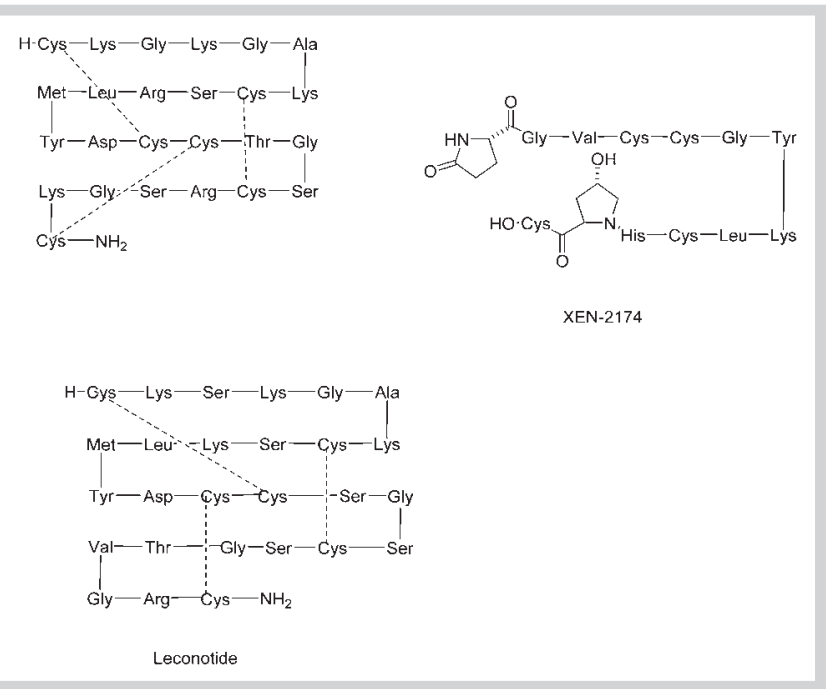

Fig. 5 Cone snail toxins.

scientists and the $\mathrm{NCI}$, eribulin would not have been approved, nor would the very interesting and novel agents referred to in the preceding paragraph have been synthesized.

\section{Ziconotide: Cone Snail Toxins as Pain Treatment $\nabla$}

The fundamental work by Olivera et al. on the peptidic neurotoxins from fish-hunting cone snails led over the next 20 or so years to a massive amount of information on the sources, the utility in both the snail, and the potential for use or leads to a drug of use in man [81]. When it was realized by Olivera and his colleagues that these peptidic toxins were very specific as to which of the cationgating channels they inhibited and/or activated, then the study of these potential neurological agents began in earnest [82].

As a result of Olivera's work at the University of Utah, a small company (Neurex) was set up to evaluate the 25-mer cyclic peptide, now known as ziconotide ( $\boldsymbol{O}$ Fig. $\mathbf{5}$ ), that was one of the many peptidic toxins found in Conus magus. Close to 200 modifications of the tricyclic peptide (three CYS-CYS linkages being the major structural motif) were synthesized and evaluated for their pharmaceutical potential but in the end, the natural product was the choice, even though made synthetically [83].

This compound (ziconotide or Prialt ${ }^{\circledR}$; $\odot$ Fig. 5 ) subsequently became the first marine-derived product to gain approval as a drug on its approval by the FDA on the 28th of December 2004, though it passed through a number of companies en route, followed rapidly by approval in the EU by the EMEA two months later. Ziconotide, though effective in its limited application, is not a drug that is taken easily as it has to be delivered via an intrathecal injection route.

\section{XEN-2174 (Phase II?)}

This compound is a very slight modification of the naturally occurring $x$-conotoxin MrIA. That compound was originally isolated from C. marmoreus and then optimized by medicinal chemistry [84]. Unlike the other conotoxins, either approved or in various levels of testing, this particular agent is a 13-residue peptide and is a noncompetitive inhibitor of the neuronal norepinephrine transporter (NET) [85]. 
The source company, Xenome, is still listed on various sites as having this compound in Phase II trials against cancer pain, and in an abrogated trial at Phase II countering pain from bunion surgery in Bulgaria under the EudraCT protocol 010-019109-40-BG. This latter trial was terminated by the FDA, but no data has yet been published. However, a search of the internet undertaken in August 10th 2015, shows that the web site "www.xenome.com" is up for sale, thus the current status of this compound is unknown, but fuller details of the development of this compound and of Prialt ${ }^{\circledR}$ were published (February 2015) in a book chapter that can be consulted for further information [86]. Due to the uncertainty as to the actual status commented on above, we have used the "Phase II?" heading for this section.

\section{Leconotide ( $\omega$-Conotoxin CVID; Phase I)}

This molecule, a 27 residue peptide with three internal CYS-CYS bonds, similar in overall structure to ziconotide, had reached Phase I trials sponsored by Relevare Pharmaceuticals (Australia; previous name was CNSBio) for treatment of pain related to cancer. It is a calcium channel blocker and was originally identified by researchers at the University of Queensland. Although initial experiments used the intrathecal route (as with ziconotide) [87], the protocol used systemic administration [88]. The company involved has now liquidated, so just as with XEN-2174, the current status is unknown.

Recently, Craik and coworkers in Australia have demonstrated that by taking structural cues from plant cyclotides, they can alter the peptide's (including cone snail toxins) pharmacological characteristics, producing oral analgesic activity in animal tests, thus opening up other methods of delivery, avoiding the very difficult current intrathecal route $[89,90]$.

As mentioned above, a recent book has chapters written by the experts in this field and we recommend that interested readers consult the chapters written in conjunction with Olivera [91] and Alewood [92] for much more background information on these very interesting natural products and derivatives.

\section{Unapproved Marine-Sourced Compounds in Current Clinical Trials \\ $\nabla$}

There are a number of marine-derived agents that have been in trials up through Phase II but for one reason or another, have not been continued. Some were for toxicity, some for lack of efficacy, but these are not discussed any further. However, in at least one case, that of a hemiasterlin derivative HTI-286 or taltobulin, the compound, though headed for Phase II, was discontinued for "business reasons" by Wyeth. The history of that particular compound was presented by Andersen et al. in 2012 [93].

However, the compounds discussed in this section are those that are not "descended from or related to" those that are currently approved, but are all in clinical trials at the time of this writing, or in some cases, the trial(s) has/have been completed, but no details have yet been published. They are divided by the disease(s) for which they are under development.

\section{Analgesia: tetrodotoxin (Phase II/III)}

Aside from the conotoxins, perhaps the most unusual agent at this stage is a very well-known "marine toxin", the highly substituted guanidine-derivative tetrodotoxin ( Fig. 6) [94-96]. WEX Pharmaceuticals has placed the compound into two Phase III trials in the USA as an agent $\left(\right.$ Tectin $^{\circledR}$ ) against inadequately con-

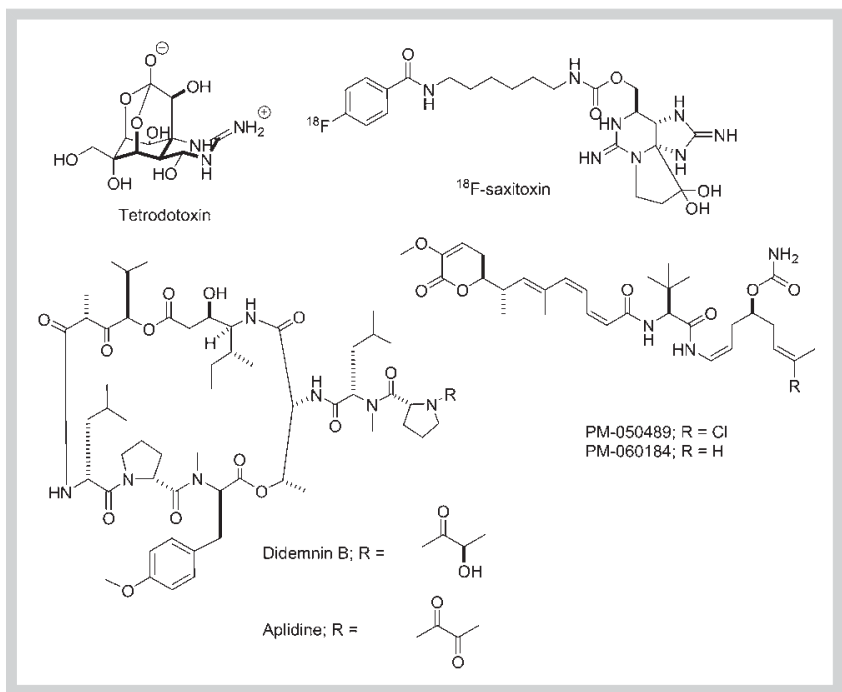

Fig. 6 Unapproved marine-sourced compounds in current clinical trials.

trolled pain related to cancer (NCT00725114; 00726011 ). One (NCT01655823), again in the USA, was terminated under the same company at Phase II (against neuropathic pain resulting from chemotherapy-induced peripheral neuropathy), because the interim results were such that they wished to move directly to a Phase III trial for the same indication.

Although there was debate in years gone by over the actual source of this agent, there is now little doubt that it is produced by a commensal microbe, though which one(s) is/are still open for debate [97]. The synthesis of the compound and other derivatives has been published from a variety of chemists, with an excellent review by Nishikawa and Isobe in 2013 [98], giving the highlights of their methodologies and covering some of the early history of this class of toxins. This paper shoud be read in conjunction with the more comprehensive review on the biology and chemistry of tetrodotoxin by Bane et al., where they even mention the 25 plus variations on the basic structure so far reported [99].

\section{PET-Imaging ${ }^{18}$ F-Saxitoxin}

For comparison, another algal/cyanophyte/bacterial product closely related to tetrodotoxin is being considered for in vivo PET-MR imaging of voltage-gated sodium channels; in this case, ${ }^{18}$ F-saxitoxin ( Fig. 6) [100]. Saxitoxin has been well described with an excellent review in 2014, so this agent may well end up not only as a curiosity but as a valuable agent from marine sources, though whether a formal clinical trial will occur is not certain [101].

\section{Antitumor Compounds}

$\nabla$

Aplidine (Plitidepsin, Phase II/III)

Aplidine, which is formally dehydrodidemnin B (० Fig. 6), is a very close chemical relative of the first direct-from-the-sea antitumor compound didemnin B (๑ Fig.6). The latter compound went to Phase II trials, but was terminated due to toxicity problems, possibly due to the method(s) of delivery, as suggested by Vera and Jouille [102]. Aplidine was originally isolated from Aplidium albicans and first reported in a patent application in 1989, 
with a UK patent issued in 1990. It was formally identified in the chemical literature in a paper from Rinehart's group in 1996 covering the structure-activity relationships amongst the didemnins [103]. The earlier work on aplidine, its entry into Phase I and II trials, and the preferred method of synthesis was described in detail through late 2004 by PharmaMar scientists [104], with further information through late 2011 by PharmaMar scientists in the second edition in 2012 of the 2005 book [46].

Currently, this agent is listed in four clinical trials by cross-referencing against the three clinical databases, one at Phase III, two at Phase II, and one Phase I. In the EudraCT clinical trials database, one Phase III trial (2009-016138-29) is listed in multiple myeloma. This is also listed in the $\mathrm{NCI}$ clinical trials database as NCT01102426, a Phase III trial with or without dexamethasone against resistant multiple myeloma, the ADMYRE trial.

There is a difference in the $\mathrm{NIH}$ and the EU databases with respect to a Phase II trial against liposarcoma, where the trial (2009010980-18) in the EU database is listed as ongoing in France, the NIH trial (NCT01876043) is listed as being terminated in early 2015, which agrees with the WHO data. However, since the WHO listing is populated by the NIH data, there is still some confusion as to the status.

The EU database still has an open Phase II trial in Spain under 2004-001 117-34 against relapsed or refractory non-Hodgkin's lymphoma, whereas the NIH database shows that the trial (NCT00884286) has been completed. There is one Phase I trial (NCT02100657) recruiting at the Phase I level for multiple myeloma that commenced in the middle of 2014. This is not shown in the EU database, but is in the WHO one, though probably populated from the NIH database.

The precise MOA of this agent in a tumor environment is not fully described, but in 2009, Munoz-Alonso et al. described some of the then known cellular interactions [105], and in 2014, scientists working with PharmaMar described the further interactions with elements of the immune system [106]. This paper should be consulted for further specific interactions. In abstracts presented at the EORTC conference in November 2014, PharmaMar scientists and colleagues reported that aplidin bound directly to the eukaryotic elongation factor $1 \mathrm{~A} 2$ (eEF1A2), a target that is overexpressed in multiple myeloma (MM) and acute lymphoblastic leukemia (ALL) $[107,108]$. For more information on these pathways, the two recent reviews from the Pelletier group at McGill University should be consulted [109,110].

\section{PM050489/PM060184 (Phase I)}

This agent, a polyketide and its chloro derivative (PM050489), was isolated from the Madagascan sponge Lithoplocamia lithistoides, with the extract demonstrating antimitotic activity and the isolated agents, tubulin-binding activities. Due to the low level of these agents in the sponge, syntheses were described by the PharmaMar group [111] in 2013. This initial paper was followed the same year with evidence for binding at or close to the vinca domain [112]. In 2014, further evidence of activity of the deschloro derivative (PM060184, ๑ Fig. 6) against P-glycoproteinexpressing tumors was published [113].

Currently, PM060184 ( Fig. 6) is in one listed Phase I trial in the NIH database (NCT01299636) that commenced in San Antonio, Texas in 2011, with the same trial listed in the WHO database and no listings in the EU database. It is listed in Phase I in the PharmaMar pipeline (accessed August 8th, 2015) and at the 2014 EORTEC Meeting, there was an interesting report of in vivo activity in mice at low levels of this agent [114].

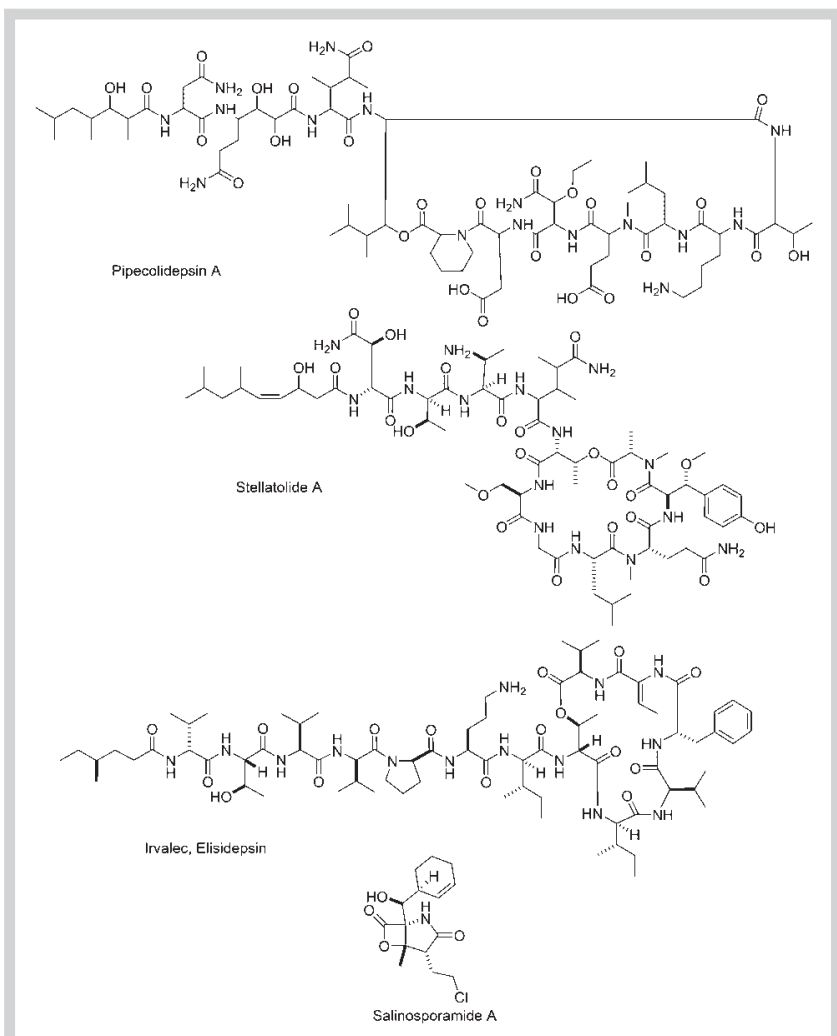

Fig. 7 Pipecolidepsin, stellatolide A, irvalec, salinosporamide A.

Also at the EORTEC 2014 meeting, there was a very interesting report from PharmaMar showing that the chloro-derivative (PM050489) could be linked to trastuzumab by reduction of the antibody with a phosphine reagent, coupling to a maleimido derivative of PM050489, followed by purification by size exclusion chromatography to yield the resulting conjugate (MI130004) [114]. This ADC showed in vitro activity when tested against cell lines with selectivity towards cell lines with high HER2 expression ( IC $_{50}$ s 0.282 and $0.182 \mathrm{nM}$ against HCC-1954 and SK-BR-3 cell lines, respectively), whilst HER2 null cells were unaffected in the range of concentrations tested (up to $300 \mathrm{nM}$ ). In vivo, MI130004 also demonstrated efficiency in causing an outstanding tumor reduction, with complete regressions in most of the animals that received the treatment [115].

\section{Pipecolidepsin, stellatolide $A$, and irvalec}

The PharmaMar group recently presented data at the 2014 EORTEC meeting that demonstrated activity in these three modified marine-derived compounds ( Fig. 7) [51,116,117]. Irvalec was pulled from clinical trials by PharmaMar at the Phase II level, so it is interesting that they are now reporting on it and the other two [118].

\section{Marizomib ${ }^{\circledR}$ (Salinosporamide A; NPI-0052; Phase II/I)}

The story of this compound from its discovery from the marine actinomycete Salinispora tropica and its identification as a proteasome inhibitor has been covered extensively in the scientific literature. These reports include a workup to give the cGMP product from the first marine medium-based large-scale fermentation through synthesis by a variety of chemists both in academia and companies, and identification of the biosynthetic cluster in 


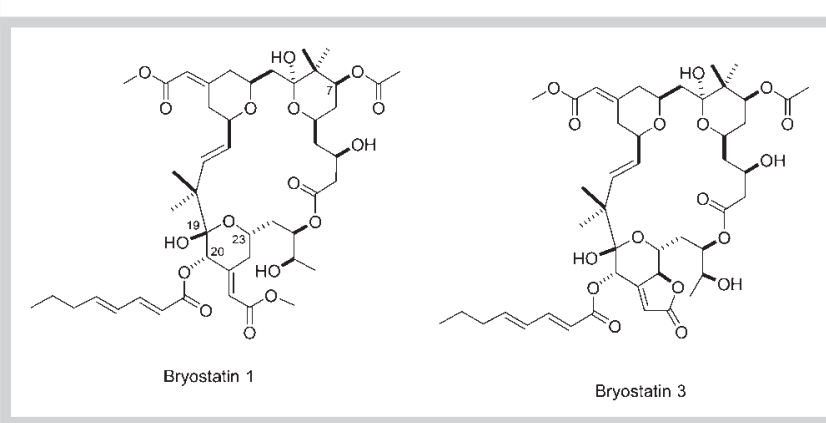

Fig. 8 Alzheimer's disease and antiviral compounds.

the producing organism(s) [119-122]. These were followed in 2014 by an excellent article by Jensen et al. giving up to date information on the genetic analyses of the producing organism and others from the same genus [123]. Then later the same year, there was a report of the first discovery of the gene cluster for salinosporamide A in Salinispora arenicola (rather than S. tropica) collected in temperate waters by Goo et al. [124].

Nereus Pharmaceuticals, the company set up to develop this compound and others from Jensen/Fenical laboratories, liquidated two or so years ago and all IP, etc., were transferred to Triphase Research and Development Corporation. Currently, in the NIH database, there are two Phase I trials "recruiting" (NCT02330562 and 02103335 ), both commencing in 2014, plus a Phase 1/II trial in multiple myeloma listed as "active but not recruiting" (NCT00461045). This latter trial started in 2007 under Nereus and from 2013, was listed under Triphase. This data is in the clinical trials archive listing, accessible from the regular $\mathrm{NIH}$ clinical trials web site.

\section{Alzheimer's Disease and Antiviral Compounds} V

\section{Bryostatin 1 (Phase II, Alzheimer's Disease)}

The isolation of the first of this 20-membered (now 21 plus vide infra) class of macrolidic cytotoxins from the fouling invertebrate Bugula neritina over 30 years ago led to massive collections of the nominal producing organism and to very elegant syntheses of various components. The initial discovery of bryostatin 3 ( Fig. 8) was indirectly reported in 1970, the subsequent developments leading to the report of the isolation and X-ray structure of bryostatin 1 ( Fig. 8) in 1982, together with the multiyear program that culminated in the isolation and purification of 18 bryostatins, have been well documented [125].

All of the known bryostatins possess a 20 -membered macrolactone ring with three remotely substituted pyran rings linked by a methylene bridge and an (E)-disubstituted alkene; all have geminal dimethyls at $\mathrm{C}_{8}$ and $\mathrm{C}_{18}$, and a four carbon side chain (carbons 4-1) from the A ring to the lactone oxygen, with another four carbon chain (carbons 24-27) on the other side of the lactone oxygen to the $\mathrm{C}$ ring. Most have an exocyclic methyl enoate in their B and C rings, though bryostatin 3, in particular, has a butenolide rather than the $C$ ring methyl enoate, and bryostatins 16 and 17 have glycals in place of the regular $C_{19}$ and $C_{20}$ hydroxyl moieties [125,126].

Work reported from the Peoples' Republic of China in 1998 [127] and in 2004 [128] gave the structure for bryostatin 19 purified from a South China Sea collection of Bugula neritina. Then, in the same year, this report was followed by the publication by Lopanik et al. reporting the isolation of bryostatin 20 from an Atlantic-sourced B. neritina [129]. Comparison with the structures of the other 18 bryostatins shows that these are closely related to bryostatin 3 in terms of their basic ring components. Very recently, the Chinese group published the structure of bryostatin 21 and also four derivatives of known bryostatins [130], so there are now 21 to 25 naturally occurring bryostatins. The substituted bryostatins $22-25$ could be artifacts of the isolation techniques used, so until further confirmation is obtained, we will use 21 bryostatins to date.

Bryostatin 1 has been through well over 80 Phase I and Phase II clinical trials, with or without the addition of a cytotoxic agent in the protocols, but in no case has the compound progressed. In some of the earlier trials, the mode of delivery (a bolus at or close to the maximum tolerated dose or MTD) may have been the major problem, as myalgia was a serious side effect.

In 2011, the Keck group reported the first complete total synthesis of bryostatin 1 [131], which was rapidly followed by a paper from Manaviazar and Hale with details of a shorter route to the same compound [132]. Later the same year, Trost et al. published papers on the ring-expanded versions of bryostatins obtained by total synthesis, so the synthetic story of this class of macrocycles has not yet finished $[133,134]$.

It is now almost certain that bryostatins are produced by an as yet uncultured microbe found initially in the larvae of the bryozoan. Current information can be obtained by inspection of the review by the Haygood group published in 2010 [135].

What is of current importance, however, is the report by Neurotrope that the Phase II a study (NCT02221947) of bryostatin 1 in Alzheimer's disease, which was terminated and replaced by the trial listed below, demonstrated that bryostatin 1 could be delivered safely to patients. The follow-on Phase II trial (NCT02431468) is listed as "not yet recruiting", effective the middle of April 2015 with Neurotrope Inc. (and is still listed the same way in late November 2015); this is in contrast to the earlier trial listed for the same indication but with no information posted since 2008 (NCT00606164) under a different sponsor.

\section{Bryostatin 1 and "Latent" HIV}

A number of simplified bryostatin analogues (often called "bryologs") have been synthesized using methods such as functionoriented synthesis. This technique was employed by Wender and other workers to develop simplified analogues with comparable or much improved activities, in some cases orders of magnitude in in vitro assays [136-138]. Further information was given in a review by Newman [139] and in a recent 2013 paper by the Keck group [140]. What is also of significant importance is the recent report by the Wender group of in vitro anti-HIV activity for some of their newer analogues [141].

In June 2015, Aphios Inc. in Massachusetts announced that they had enrolled patients for a Phase I/II study of bryostatin 1 in a trial that is designed to "release" the HIV virions from their latent sites in patients. This is a well-known phenomenon of a number of viruses including HIV, and is the basis of the anti-HIV treatment known as HAART (highly active antiretroviral therapy). These trials are being conducted in Spain, with a Phase I record under NCT02269605. Bryostatin 1 was produced using Aphios' now patented supercritical fluid technique, which was used, though not under cGMP conditions, as a comparator many years ago in bryostatin 1 purification processes [142]. 
Though bryologs have now yet been tried, if these trials are successful, then it is feasible that one or more of the Wender or Keck compounds could be a candidate for trials against HIV or other viruses that exhibit latency, such as the herpes simplex complex.

\section{Griffithsin (Microbial Virucide Headed for Clinical Trials)}

This 121-residue peptidic agent was first reported in 2005 following its isolation from the red alga Griffithsia sp. Due to source constraints, it was subsequently produced by transfer of the DNA sequence corresponding to the peptide via a plasmid into, and subsequent expression in, Escherichia coli [143]. The material, either natural or recombinant, was ultimately shown to bind to specific mannose-rich regions of HIV viral proteins [144]. In 2009 , it was reported that the compound could function as a topical microbicide with potential as an intra-vaginal agent to protect against HIV transmission [145]. Since that publication, work has continued with this compound by demonstrating large-scale production in plants [145], further efficacy [146], and toxicity studies in rodent models [147].

Currently, the Population Council is developing a griffithsin-containing microbicide to prevent the transmission of HIV and other sexually transmitted infections (http://www.popcouncil.org/ research/developing-and-testing-a-griffithsin-non-arv-microbicide). That web site has the following statement: "In 2013, the Council was awarded a cooperative agreement from PEPFAR, and administered by USAID, to investigate griffithsin (GRFT) as a vaginal microbicide. GRFT is a naturally occurring protein isolated from algae that has potent activity against HIV and other STIs. GRFT for drug development is produced in tobacco plants, and initial pre-clinical testing has shown it to be safe and nonirritating in vitro (in cells and tissue) and in vivo (in animals). Council researchers are developing a GRFT-containing microbicide gel for pre-clinical and clinical studies. Results from these studies will inform the development of other delivery systems, including an intravaginal ring to provide protection immediately and up to 90 days." (accessed August 17th, 2015).

\section{In Conclusion}

$\nabla$

In this review, we initially concentrated on materials that are approved as drugs by the relevant authorities. In addition, we have discussed compounds that are chemically related to those approved drugs, and then compounds that are in clinical trials mainly against cancer, but also Alzheimer's disease and HIV. The emphasis on cancer is simply due to the fact that the major funding agency for marine-derived compounds for many years was the $\mathrm{NIH} / \mathrm{NCI}$, and to some extent, this carried over in other countries.

There are a large number of very interesting compounds that have been isolated, usually via activity-driven isolation processes from single-celled organisms, in particular the cyanobacteria. There are some excellent current reviews covering compounds from these photosynthetic bacteria that have bioactivities ranging from antitumor to neurological diseases, but none have yet made it to clinical trials [148-150]. What is noticeable, however, is that no antimicrobial compounds from marine sources have yet made it beyond the discovery phase into what is known in the pharmaceutical industry as "the preclinical phase". This may well be a function of the current lack of antimicrobial research in the major pharmaceutical companies (which used to be a major source of natural product-based compounds), coupled to a lack of funding in this area for both discovery and, particularly, development. However, a very recent review by $\mathrm{Ng}$ et al. demonstrates that there are definitely possibilities in these disease areas for marine-sourced compounds [151].

Finally, we consider that the potential for marine-based compounds in all disease areas is immense. When one realizes that currently there are approximately 25000 defined chemical compounds reported to date from marine sources, and there are seven approved drugs [(including the omaga-3-acid ethyl esters and vidarabine not discussed in this article [152], and one may also check the web site of Professor A.M.S. Mayer in the USA (http://marine pharmacology.midwestern.edu/clinPipeline.htm) for these sources (direct or modified structures)], then a success ratio of 1 in 3500 is orders of magnitude better those from synthetic molecules.

\section{Conflict of Interest \\ $\nabla$}

Both authors declare that there are no conflicts of interest with the content of this manuscript.

\section{References}

1 Ramirez-Llodra E, Brandt A, Danovaro R, De Mol B, Escobar E, German $C R$, Levin LA, Martinez Arbizu P, Menot L, Buhl-Mortensen P, Narayanaswamy BE, Smith CR, Tittensor DP, Tyler PA, Vanreusel A, Vecchione $M$. Deep, diverse and definitely different: unique attributes of the world's largest ecosystem. Biogeosciences 2010; 7: 2851-2899

2 Arrieta JM, Arnaud-Haond S, Duarte CM. What lies underneath: conserving the oceans' genetic resources. Proc Natl Acad Sci U S A 2010; 107: 18318-18324

3 Gage JD, Tyler PA. Deep-sea biology: a natural history of organisms at the deep-sea floor. Cambridge, UK: Cambridge University Press; 1991: $1-504$

4 Hagiwara H, Numata M, Konishi K, Oka Y. Synthesis of nereistoxin and related compounds. I. Chem Pharm Bull (Tokyo) 1965; 13: 253-260

5 Ruggieri GD. Drugs from the Sea. Science 1976; 194: 491-497

6 Suckling CJ. Chemical approaches to the discovery of new drugs. Sci Prog 1991; 75: 323-359

7 Newman DJ, Cragg GM, Snader KM. The influence of natural products upon drug discovery. Nat Prod Rep 2000; 17: 215-234

8 Bergmann W, Feeney RJ. Isolation of a new thymine pentoside from sponges. J Am Chem Soc 1950; 72: 2809-2810

9 Bergmann W, Feeney RJ. Marine products. XXXII. The nucleosides of sponges. I. J Org Chem 1951; 16: 981-987

10 Bergmann W, Burke DC. Marine products. XXXIX. The nucleosides of sponges. III. Spongothymidine and spongouridine. J Org Chem 1955; 20: $1501-1507$

11 Löwenberg $B$. Sense and nonsense of high-dose cytarabine for acute myeloid leukemia. Blood 2013; 121: 26-28

12 Cimino G, De Rosa S, De Stefano S. Antiviral agents from a gorgonian, Eunicella cavolini. Experientia 1984; 40: 339-340

13 Bertin MJ, Schwartz SL, Lee J, Korobeynikov A, Dorrestein PC, Gerwick L, Gerwick WH. Spongosine production by a Vibrio harveyi strain associated with the sponge Tectitethya crypta. J Nat Prod 2015; 78: 493-499

14 Flahive E, Srirangam J. The dolastatins: novel antitumor agents from Dolabella auricularia. In: Cragg GM, Kingston DGI, Newman DJ, editors. Anticancer agents from natural products. Boca Raton, FL: Taylor and Francis; 2005: 191-213

15 Flahive E, Srirangam J. The dolastatins: novel antitumor agents from Dolabella auricularia. In: Cragg GM, Kingston DGI, Newman DJ, editors. Anticancer agents from natural products, 2nd edition. Boca Raton, FL: Taylor and Francis; 2012: 263-289

16 Luesch H, Moore RE, Paul VJ, Mooberry SL, Corbett TH. Isolation of dolastatin 10 from the marine cyanobacterium Symploca species VP642 and total stereochemistry and biological evaluation of its analogue symplostatin 1. J Nat Prod 2001; 64: 907-910

17 Engene N, Tronholm A, Salvador-Reyes LA, Luesch H, Paul VJ. Caldora penicillata gen. nov., comb. nov. (Cyanobacteria), a pantropical marine species with biomedical relevance. J Phycol 2015; 51: 670-681 
18 Doronina SO, Mendelsohn BA, Bovee TD, Cerveny CG, Alley SC, Meyer DL, Oflazoglu E, Toki BE, Sanderson RJ, Zabinski RF, Wahl AF, Senter PD. Enhanced activity of monomethylauristatin $\mathrm{F}$ through monoclonal antibody delivery: effects of linker technology on efficacy and toxicity. Bioconjug Chem 2006; 17: 114-124

19 Copeland A, Younes A. Brentuximab vedotin. Anti-CD30 antibody-drug conjugate, oncolytic. Drugs Fut 2010; 35: 797-801

20 Ansell SM. Brentuximab vedotin: delivering an antimitotic drug to activated lymphoma cells. Expert Opin Investig Drugs 2011; 20: 99-105

21 Haddley $K$. Brentuximab vedotin: its role in the treatment of anaplastic large cell and Hodgkin's lymphoma. Drugs Today (Barc) 2012; 48: 259270

22 Newland AM, Li JX, Wasco LE, Aziz MT, Lowe DK. Brentuximab vedotin: a CD30-directed antibody-cytotoxic drug conjugate. Pharmacotherapy 2013; 33: 93-104

23 Newman DJ, Cragg GM. Marine-sourced anti-cancer and cancer pain control agents in clinical and late preclinical development. Mar Drugs 2014; 12: 255-278

24 Smaglo BG, Aldeghaither D, Weiner LM. The development of immunoconjugates for targeted cancer therapy. Nat Rev Clin Oncol 2014; 11 : 637-648

25 Tse KF, Jeffers M, Pollack VA, McCabe DA, Shadish ML, Khramtsov NV, Hackett CS, Shenoy SG, Kuang B, Boldog FL, MacDougall JR, Rastelli L, Herrmann J, Gallo M, Gazit-Bornstein G, Senter PD, Meyer DL, Lichenstein HS, LaRochelle WJ. CR011, a fully human monoclonal antibody-auristatin E conjugate, for the treatment of melanoma. Clin Cancer Res 2006; 12: 1373-1382

26 Pollack VA, Alvarez E, Tse KF, Torgov MY, Xie S, Shenoy SG, MacDougall JR, Arrol S, Zhong H, Gerwien RW, Hahne WF, Senter PD, Jeffers ME, Lichenstein HS, LaRochelle WJ. Treatment parameters modulating regression of human melanoma xenografts by an antibody-drug conjugate (CR011-vcMMAE) targeting GPNMB. Cancer Chemother Pharmacol 2007; 60: 423-435

27 Rose AA, Grosset AA, Dong Z, Russo C, Macdonald PA, Bertos NR, St-Pierre Y, Simantov R, Hallett M, Park M, Gaboury L, Siegel PM. Glycoprotein nonmetastatic $B$ is an independent prognostic indicator of recurrence and a novel therapeutic target in breast cancer. Clin Cancer Res 2010; 16: 2147-2156

28 Zhou LT, Liu FY, Li Y, Peng YM, Liu YH, Li J. Gpnmb/osteoactivin, an attractive target in cancer immunotherapy. Neoplasma 2012; 59: 1-5

29 Vaklavas C, Forero A. Management of metastatic breast cancer with second-generation antibody-drug conjugates: focus on glembatumumab vedotin (CDX-011, CR011-vcMMAE). BioDrugs 2014; 28: 253-263

30 Bendell J, Saleh M, Rose AA, Siegel PM, Hart L, Sirpal S, Jones S, Green J, Crowley E, Simantov R, Keler T, Davis T, Vahdat L. Phase I/II study of the antibody-drug conjugate glembatumumab vedotin in patients with locally advanced or metastatic breast cancer. J Clin Oncol 2014; 32: 3619-3625

31 Yardley DA, Weaver R, Melisko ME, Saleh MN, Arena FP, Forero A, Cigler T, Stopeck A, Citrin D, Oliff I, Bechhold R, Loutfi R, Garcia AA, Cruickshank S, Crowley E, Green J, Hawthorne T, Yellin MJ, Davis TA, Vahdat LT. EMERGE: A Randomized Phase II Study of the Antibody-Drug Conjugate Glembatumumab Vedotin in Advanced Glycoprotein NMB-Expressing Breast Cancer. J Clin Oncol 2015; 33: 1609-1619

32 Ott PA, Hamid O, Pavlick AC, Kluger H, Kim KB, Boasberg PD, Simantov R, Crowley E, Green JA, Hawthorne T, Davis TA, Sznol M, Hwu P. Phase I/II study of the antibody-drug conjugate glembatumumab vedotin in patients with advanced melanoma. J Clin Oncol 2014; 32: 3659-3666

33 Li D, Poon KA, Yu SF, Dere R, Go M, Lau J, Zheng B, Elkins K, Danilenko D, Kozak KR, Chan P, Chuh J, Shi X, Nazzal D, Fuh F, McBride J, Ramakrishnan $V$, de Tute R, Rawstron A, Jack AS, Deng R, Chu YW, Dornan D, Williams M, Ho W, Ebens A, Prabhu S, Polson AG. DCDT2980 S, an anti-CD22-monomethyl auristatin $\mathrm{E}$ antibody-drug conjugate, is a potential treatment for non-Hodgkin lymphoma. Mol Cancer Ther 2013; 12: 1255-1265

34 Gordon MS, Gerber DE, Infante JR, Xu J, Shames DS, Choi Y, Kahn RS, Lin K, Wood K, Maslyar DJ, Burris HA. A phase I study of the safety and pharmacokinetics of DNIB0600 A, an anti-NaPi2b antibody-drug-conjugate (ADC), in patients (pts) with non-small cell lung cancer (NSCLC) and platinum-resistant ovarian cancer (OC).J Clin Oncol 2013; 31: Abstr. 2507

35 Lin K, Sukumaran S, Xu J, Zhang C, Choi Y, Yu S, Polakis P, Maslyar D. Translational PKPD of DNIB0600 A, an anti-Napi2b-vc-MMAE ADC in ovarian and NSCLC cancers. Ann Oncol 2014; 25: Abstr. 1598P

36 Bhakta S, Junutula JR. Cysteine engineered antibodies and conjugates. US Patent 2011/0301334 A1; 7th June 2011
37 Boswell CA, Mundo EE, Zhang C, Bumbaca D, Valle NR, Kozak KR, Fourie A, Chuh J, Koppada N, Saad O, Gill H, Shen BQ Rubinfeld B, Tibbitts J, Kaur $S$, Theil FP, Fielder PJ, Khawli LA, Lin K. Impact of drug conjugation on pharmacokinetics and tissue distribution of anti-STEAP1 antibodydrug conjugates in rats. Bioconjug Chem 2011; 22: 1994-2004

38 Lin K, Tibbitts J. Pharmacokinetic considerations for antibody drug conjugates. Pharm Res 2012; 29: 2354-2366

39 Danila DC, Szmulewitz RZ, Higano CS, Gilbert H, Kahn RS, Wood K, Agarwal P, Lin K, Kabbarah O, Fine BM, Maslyar DJ, Vaishampayan UN. A phase I study of the safety and pharmacokinetics of DSTP3086S, an anti-STEAP1 antibody-drug conjugate (ADC), in patients (pts) with metastatic castration-resistant prostate cancer (CRPC). J Clin Oncol 2013; 31: Abstr. 5020

40 Danila DC, Szmulewitz RZ, Baron AD, Higano CS, Scher HI, Morris MJ, Gilbert H, Brunstein F, Lemahieu V, Kabbarah O, Fine BM, Maslyar DJ, Vaishampayan UN. A phase I study of DSTP3086 S, an antibody-drug conjugate (ADC) targeting STEAP-1, in patients (pts) with metastatic castration-resistant prostate cancer (CRPC). J Clin Oncol 2014; 32: Abstr. 5024

41 Sigel MM, Wellham LL, Lichter W, Dudeck LE, Gargus JL, Lucas LH. Anticellular and antitumor activity of extracts from tropical marine invertebrates. In: Youngken HW jr., editor. Food-drugs from the sea: proceedings 1969. Washington, D. C.: Marine Technology Society; 1970: 281-294

42 Holt TG. The isolation and structural characterization of the ecteinascidins [dissertation]. Urbana-Champaign: University of Illinois; 1986

43 Rinehart K, Holt TG, Fregeau NL, Stroh JG, Kiefer PA, Sun F, Li LH, Martin $D G$. Ecteinascidins 729, 743, 745, 759 A, 759B and 770: potent antitumor agents from the Caribbean tunicate Ecteinascidia turbinata. J Org Chem 1990; 55: 4512-4515

44 Wright AE, Forleo DA, Gunawardana GP, Gunasekera SP, Koehn FE, McConnell OJ. Antitumor tetrahydroisoquinoline alkaloids from the colonial ascidian Ecteinascidia turbinata. J Org Chem 1990; 55: 4508-4512

45 Cuevas C, Francesch A. Development of Yondelis ${ }^{\circledR}$ (trabectedin, ET-743). A semisynthetic process solves the supply problem. Nat Prod Rep 2009; 26: 322-337

46 Cuevas C, Francesch A, Galmarini CM, Aviles P, Munt S. Ecteinascidin743 (Yondelis $^{\circledR}$ ), Aplidin ${ }^{\circledR}$, and Irvalec ${ }^{\circledR}$. In: Cragg GM, Kingston DGI, Newman DJ, editors. Anticancer agents from natural products, 2nd edition. Boca Raton, FL: Taylor and Francis; 2012: 291-316

47 Soares DG, Escargueil AE, Poindessous V, Sarasin A, de Gramont A, Bonatto $D$, Henriques JAP, Larsen $A K$. Replication and homologous recombination repair regulate DNA double-strand break formation by the antitumor alkylator ecteinascidin 743. Proc Natl Acad Sci U S A 2007; 04 13062-13067

48 D'Incalci M, Badri N, Galmarini CM, Allavena P. Trabectedin, a drug acting on both cancer cells and the tumour microenvironment. Br J Cancer 2014; 111: 646-650

49 Martínez S, Pérez L, Galmarini CM, Aracil M, Tercero JC, Gago F, Albella B, Bueren JA. Inhibitory effects of marine-derived DNA-binding anti-tumour tetrahydroisoquinolines on the Fanconi anaemia pathway. $\mathrm{Br} \mathrm{J}$ Pharmacol 2013: 170: 871-882

50 Romano M, Frapolli R, Zangarini M, Bello E, Porcu L, Galmarini CM, Garcia-Fernandez LF, Cuevas C, Allavena P, Erba E, D'Incalci M. Comparison of in vitro and in vivo biological effects of trabectedin, lurbinectedin (PM01183) and Zalypsis ${ }^{\circledR}$ (PM00104). Int J Cancer 2013; 133: 2024 2033

51 Martín MJ, Rodríguez-Acebes R, García-Ramos Y, Martínez V, Murcia C, Digón I, Marco I, Pelay-Gimeno M, Fernández R, Reyes F, Francesch AM, Munt S, Tulla-Puche J, Albericio F, Cuevas C. Stellatolides, a new cyclodepsipeptide family from the sponge Ecionemia acervus: isolation, solid-phase total synthesis, and full structural assignment of stellatolide A. J Am Chem Soc 2014; 136: 6754-6762

52 Yap TA, Cortes-Funes H, Shaw H, Rodriguez R, Olmos D, Lal R, Fong PC, Tan DS, Harris D, Capdevila J, Coronado C, Alfaro V, Soto-Matos A, Fernández-Teruel C, Siguero M, Tabernero JM, Paz-Ares L, de Bono JS, López-Martin JA. First-in-man phase I trial of two schedules of the novel synthetic tetrahydroisoquinoline alkaloid PM00104 (Zalypsis) in patients with advanced solid tumours. Br J Cancer 2012; 106: 1379-1385

53 Giddings LA, Newman DJ. Microbial natural products: molecular blueprints for antitumor drugs. J Ind Microbiol Biotechnol 2013; 40: $1181-1210$

54 Schofield MM, Jain S, Porat D, Dick GJ, Sherman DH. Identification and analysis of the bacterial endosymbiont specialized for production of 
the chemotherapeutic natural product ET-743. Environ Microbiol 2015; 17: 3964-3975

55 Wilson MC, Mori T, Ruckert C, Uria AR, Helf MJ, Takada K, Gernert C, Steffens UAE, Heycke N, Schmitt S, Rinke C, Helfrich EJN, Brachmann AO, Gurgui C, Wakimoto T, Kracht M, Crusemann M, Hentschel U, Abe I, Matsunaga S, Kalinowski J, Takeyama H, Piel J. An environmental bacterial taxon with a large and distinct metabolic repertoire. Nature 2014; 506: 58-62

56 Leal JF, Martínez-Díez M, García-Hernández V, Moneo V, Domingo A, Bueren-CalabuigJA, Negri A, Gago F, Guillén-Navarro MJ, Avilés P, Cuevas C, García-Fernández LF, Galmarini CM. PM01183, a new DNA minor groove covalent binder with potent in vitro and in vivo anti-tumour activity. Br J Pharmacol 2010; 161: 1099-1110

57 Soares DG, Machado MS, Rocca CJ, Poindessous V, Ouaret D, Sarasin A, Galmarini CM, Henriques JA, Escargueil AE, Larsen AK. Trabectedin and its C subunit modified analogue PM01183 attenuate nucleotide excision repair and show activity toward platinum-resistant cells. Mol Cancer Ther 2011; 10: 1481-1489

58 Fontana A, Cavaliere P, Wahidullah S, Naik CG, Cimino G. A new antitumor isoquinoline alkaloid from the marine numdibranch Jorunna $f u-$ nebris. Tetrahedron 2000; 56: 7305-7308

59 Saito N, Tanaka C, Koizumi YI, Suwanborirux K, Amnuoypol S, Pummangura S, Kubo A. Chemistry of renieramycins. Part 6: Transformation of renieramycin $M$ into jorumycin and renieramycin J including oxidative degradation products, mimosamycin, renierone, and renierol acetate. Tetrahedron 2004; 60: 3873-3881

60 Cuevas C, Perez M, Francesch A, Fernandez C, Chicharro JL, Gallego P, Zarzuelo M, De la Calle F, Manzanares I. Preparation of ecteinascidin analogs as antitumor agents. Assignee: Pharma Mar, S.A., Spain; Ruffles, Graham Keith. Patent Information: Nov 23, 2000, WO 2000069862A2

61 Leal JF, Garcia-Hernandez V, Moneo V, Domingo A, Bueren-Calabuig JA, Negri A, Gago F, Gulillen-Navarro MJ, Aviles P, Cuevas C, Garcia-Fernandez LF, Galimarini CM. Molecular pharmacology and antitumor activity of Zalypsis ${ }^{\circledR}$ in several human cell lines. Biochem Pharmacol 2009; 78: 162-170

62 Aicher TD, Buszek KR, Fang FG, Forsyth CJ, Jung SH, Kishi Y, Matelich MC, Scola PM, Spero DM, Yoon SK. Total synthesis of halichondrin B and norhalichondrin B. J Am Chem Soc 1992; 114: 3162-3164

63 Yu MJ, Kishi Y, Littlefield BA. Discovery of E7389, a fully synthetic macrocyclic ketone analog of halichondrin B. In: Cragg GM, Kingston DGI, Newman DJ, editors. Anticancer agents from natural products. Boca Raton, FL: Taylor and Francis; 2005: 241-265

64 Jordan MA, Kamath K, Manna T, Okouneva T, Miller HP, Davis C, Littlefield $B A$, Wilson $L$. The primary antimitotic mechanism of action of the synthetic halichondrin E7389 is suppression of microtubule growth. Mol Cancer Ther 2005; 4: 1086-1095

65 Jordan MA, Kamath K. How do microtubule-targeted drugs work? An overview. Curr Cancer Drug Targets 2007; 7: 730-742

66 Okouneva T, Azarenko O, Wilson L, Littlefield BA, Jordan MA. Inhibition of centromere dynamics by Eribulin (E7389) during mitotic metaphase. Mol Cancer Ther 2008; 7: 2003-2011

67 Smith JA, Wilson L, Azarenko O, Zhu X, Lewis BM, Littlefield BA, Jordan $M A$. Eribulin binds at microtubule ends to a single site on tubulin to suppress dynamic instability. Biochemistry 2010; 49: 1331-1337

68 Wang Y, Serradell N, Bolos J, Rosa E. Eribulin mesilate. Drugs Fut 2007; 32: 681-698

69 Dong CG, Henderson JA, Kaburagi Y, Sasaki T, Kim DS, Kim JT, Urabe D, Guo H, Kishi Y. New syntheses of E7389 C14-C35 and halichondrin C14-C38 building blocks: reductive cyclization and oxy-Michael cyclization approaches. J Am Chem Soc 2009; 131: 15642-15646

70 Kim DS, Dong CG, Kim JT, Guo H, Huang J, Tiseni PS, Kishi Y. New syntheses of E7389 C14-C35 and halichondrin C14-C38 building blocks: double-inversion approach. J Am Chem Soc 2009; 131: 15636-15641

71 Yang YR, Kim DS, Kishi Y. Second generation synthesis of C27-C35 building block of E7389, a synthetic halichondrin analogue. Org Lett 2009; 11: 4516-4519

72 Jackson KL, Henderson JA, Motoyoshi H, Phillips AJ. A total synthesis of Norhalichondrin B. Angew Chem Int Ed 2009; 48: 2346-2350

73 Jackson KL, Henderson JA, Phillips AJ. The halichondrins and E7389. Chem Rev 2009; 109: 3044-3079

74 Chase CE, Fang FG, Lewis BM, Wilkie GD, Schnaderbeck MJ, Zhu X. Process development of Halaven ${ }^{\circledR}$ : Synthesis of the $\mathrm{C} 1-\mathrm{C} 13$ fragment from d(-)-gulono-1, 4-lactone. Synlett 2013; 24: 323-326

75 Austad BC, Benayoud F, Calkins TL, Campagna S, Chase CE, Choi H-w, Christ W, Costanzo R, Cutter J, Endo A, Fang FG, Hu Y, Lewis BM, Lewis
MD, McKenna S, Noland TA, Orr JD, Pesant M, Schnaderbeck MJ, Wilkie GD, Abe T, Asai N, Asai Y, Kayano A, Kimoto Y, Komatsu Y, Kubota M, Kuroda H, Mizuno M, Nakamura T, Omae T, Ozeki N, Suzuki T, Takigawa T, Watanabe T, Yoshizawa K. Process development of Halaven ${ }^{\circledR}$ : Synthesis of the C14-C35 fragment via iterative Nozaki-Hiyama-Kishi reactionWilliamson ether cyclization. Synlett 2013; 24: 327-332

76 Austad BC, Calkins TL, Chase CE, Fang FG, Horstmann TE, Hu Y, Lewis BM, Niu X, Noland TA, Orr JD, Schnaderbeck MJ, Zhang H, Asakawa N, Asai N, Chiba H, Hasebe T, Hoshino Y, Ishizuka H, Kajima T, Kayano A, Komatsu Y, Kubota M, Kuroda H, Miyazawa M, Tagami K, Watanabe T. Commercial manufacture of Halaven ${ }^{\circledR}$ : Chemoselective transformations en route to structurally complex macrocyclic ketones. Synlett 2013; 24: 333-337

77 Yu MJ, Zheng W, Seletsky BM. From micrograms to grams: scale-up synthesis of eribulin mesylate. Nat Prod Rep 2013; 30: 1158-1164

78 Narayan S, Carlson EM, Cheng H, Du H, Hu Y, Jiang Y, Lewis BM, Seletsky $B M$, Tendyke K, Zhang H, Zheng W, Littlefield BA, Towle MJ, Yu MJ. Novel second generation analogs of eribulin. Part I: Compounds containing a lipophilic C32 sidechain overcome P-glycoprotein susceptibility. Bioorg Med Chem Lett 2011; 21: 1630-1633

79 Narayan S, Carlson EM, Cheng H, Condon K, Du H, Eckley S, Hu Y, Jiang Y, Kumar V, Lewis BM, Saxton P, Schuck E, Seletsky BM, Tendyke K, Zhang H, Zheng W, Littlefield BA, Towle MJ, Yu MJ. Novel second generation analogs of eribulin. Part II: Orally available and active against resistant tumors in vivo. Bioorg Med Chem Lett 2011; 21: 1634-1638

80 Narayan S, Carlson EM, Cheng H, Condon K, Du H, Eckley S, Hu Y, Jiang Y, Kumar V, Lewis BM, Saxton P, Schuck E, Seletsky BM, Tendyke K, Zhang H, Zheng W, Littlefield BA, Towle MJ, Yu MJ. Novel second generation analogs of eribulin. Part III: Blood-brain barrier permeability and in vivo activity in a brain tumor model. Bioorg Med Chem Lett 2011; 21: 1639-1643

81 Olivera BM, Gray WR, Zeikus R. Peptide neurotoxins from fish-hunting cone snails. Science 1985; 230: 1338-1343

82 Olivera BM, Cruz LJ, de Santos V, LeCheminant GW, Griffin D, Zeikus $R$, McIntosh JM, Galyean R, Varga J, Gray WR, Rivier J. Neuronal calcium channel antagonists. Discrimination between calcium channel subtypes using omega-conotoxin from Conus magus venom. Biochemistry 1987; 26: 2086-2090

83 Bowersox S, Tich N, Mayo M, Luther R. SNX-111. Drugs Fut 1998; 23: $152-160$

84 Brust A, Palant E, Croker DE, Colless B, Drinkwater R, Patterson B, Schroeder CI, Wilson D, Nielsen CK, Smith MT, Alewood D, Alewood PF, Lewis RJ. $X$-Conopeptide pharmacophore development: toward a novel class of norepinephrine transporter inhibitor (Xen2174) for pain. J Med Chem 2009; 52: 6991-7002

85 Sharpe IA, Palant E, Schroeder CI, Kaye DM, Adams DJ, Alewood PF, Lewis $R J$. Inhibition of the norepinephrine transporter by the venom peptide chi-MrIA. Site of Action, $\mathrm{Na}^{+}$dependence, and structure-activity relationship. J Biol Chem 2003; 278: 40317-40322

86 Lewis RJ. Case study 1: development of the analgesic drugs Prialt ${ }^{\circledR}$ and Xen2174 from cone snail venoms. In: King GF, editor. Venoms to drugs: venom as a source for the development of human therapeutics. Abington, UK: Marston; 2015: 245-254

87 Jayamanne A, Jeong HJ, Schroeder CJ, Lewis RJ, Christie MJ, Vaughan CW. Spinal actions of omega-conotoxins, CVID, MVIIA and related peptides in a rat neuropathic pain model. Br J Pharmacol 2013; 170: 245-254

88 Daly NL, Craik DJ. Conopeptides as novel options for pain management. Drugs Future 2011; 36: 25-32

89 Clark RJ, Jensen J, Nevin ST, Callaghan BP, Adams DJ, Craik DJ. The engineering of an orally active conotoxin for the treatment of neuropathic pain. Angew Chem Int Ed 2010; 49: 6545-6548

90 Akondi KB, Muttenthaler M, Dutertre S, Kaas Q Craik DJ, Lewis RJ, Alewood PF. Discovery, synthesis, and structure-activity relationships of conotoxins. Chem Rev 2014; 114: 5815-5847

91 Teichert RW, Olivera BM, McIntosh JM, Bulaj G, Horvath MP. The molecular diversity of conoidean venom peptides and their targets: from basic research to therapeutic applications. In: King GF, editor. Venoms to drugs: venom as a source for the development of human therapeutics. Abington, UK: Marston; 2015: 163-203

92 Lavergne V, Alewood PF, Mobli M, King GF. The structural universe of disulfide-rich venom peptides. In: King GF, editor. Venoms to drugs: venom as a source for the development of human therapeutics. Abington, UK: Marston; 2015: 37-79

93 Andersen RJ, Williams DE, Strangman WE, Roberge M. HTI-286 (Taltobulin). A synthetic analog of the antimitotic natural product, hemiasterlin. In: Cragg GM, Kingston DGI, Newman DJ, editors. Anticancer agents 
from natural products, 2nd edition. Boca Raton, FL: Taylor and Francis; 2012: 347-362

94 Nieto FR, Cobos EJ, Tejada MÁ, Sánchez-Fernández C, González-Cano R, Cendán CM. Tetrodotoxin (TTX) as a therapeutic agent for pain. Mar Drugs 2012; 10: 281-305

95 Turabi A, Plunkett AR. The application of genomic and molecular data in the treatment of chronic cancer pain. J Surg Oncol 2012; 105: 494501

96 Moczydlowski EG. The molecular mystique of tetrodotoxin. Toxicon 2013; 63: 165-183

97 Chau R, Kalaitzis JA, Neilan BA. On the origins and biosynthesis of tetrodotoxin. Aquat Toxicol 2011; 104: 61-72

98 Nishikawa T, Isobe M. Synthesis of tetrodotoxin, a classic but still fascinating natural product. Chem Rec 2013; 13: 286-302

99 Bane V, Lehane M, Dikshit M, O'Riordan A, Furey A. Tetrodotoxin: chemistry, toxicity, source, distribution and detection. Toxins (Basel) 2014; 6: 693-755

100 Hoehne A, Behera D, Parsons WH, James ML, Shen B, Borgohain P, Bodapati D, Prabhakar A, Gambhir SS, Yeomans DC, Biswal S, Chin FT, Du Bois J. A ${ }^{18}$ F-labeled saxitoxin derivative for in vivo PET-MR imaging of voltage-gated sodium channel expression following nerve injury. J Am Chem Soc 2013; 135: 18012-18015

101 Thottumkara AP, Parsons WH, Du Bois J. Saxitoxin. Angew Chem Int Ed 2014; 53: 5760-5784

102 Vera M, Joullie MM. Natural products as probes of cell biology: 20 years of didemnin research. Med Res Rev 2002; 22: 102-145

103 Sakai R, Rinehart KL, Kishore V, Kundu B, Faircloth G, Gloer JB, Carney $J R$, Manikoshi M, Sun F, Hughes RG jr., Garcia-Gravalos D, Garcia de Quesada T, Wilson GR, Heid RM. Structure-activity relationships of the didemnins. J Med Chem 1996; 9: 2819-2834

104 Henriquez R, Faircloth G, Cuevas C. Ecteinascidin 743 (ET-743; Yondelis ${ }^{\mathrm{TM}}$ ), aplidin, and kahalalide F. In: Cragg GM, Kingston DGI, Newman DJ, editors. Anticancer agents from natural products. Boca Raton, FL: Taylor and Francis; 2005: 215-240

105 Munoz-Alonso MJ, Gonzalez-Santiago L, Martinez T, Losada A, Galmarini CM, Munoz A. The mechanism of action of plitidepsin. Curr Opin Investig Drugs 2009; 10: 536-542

106 Galmarini CM, D'Incalci M, Allavena P. Trabectedin and plitidepsin: drugs from the sea that strike the tumor microenvironment. Mar Drugs 2014; 12: 719-733

107 García C, Losada A, Molina-Guijarro JM, Sacristán MA, Martinez J, Galmarini CM, Lillo MP. Interaction of plitidepsin with eEF1 A in living tumor cells. Eur J Cancer 2014; 50: 111-112

108 Losada A, Martinez JF, Moral P, Carrasco L, Gago F, Cuevas C, García-Fernández LF, Galmarini CM. Aplidin: first in class compound targeting EEF1 A in tumor cells. Eur J Cancer 2014; 50: 108

109 Bhat M, Robichaud N, Hulea L, Sonenberg N, Pelletier J, Topisirovic I. Targeting the translation machinery in cancer. Nat Rev Drug Discov 2015; $14: 261-278$

$110 \mathrm{Chu}$ J, Pelletier J. Targeting the eIF4 A RNA helicase as an anti-neoplastic approach. Biochim Biophys Acta 2015; 1849: 781-791

111 Martín MJ, Coello L, Fernández R, Reyes F, Rodríguez A, Murcia C, Garranzo M, Mateo C, Sánchez-Sancho F, Bueno S, de Eguilior C, Francesch A, Munt S, Cuevas C. Isolation and first total synthesis of PM050489 and PM060184, two new marine anticancer compounds. J Am Chem Soc 2013: 135: 10164-10171

112 Pera B, Barasoain I, Pantazopoulou A, Canales A, Matesanz R, Rodriguez-Salarichs J, García-Fernandez LF, Moneo V, Jimenez-Barbero J, Galmarini CM, Cuevas C, Penalva MA, Díaz JF, Andreu JMI. New interfacial microtubule inhibitors of marine origin, PM050489/PM060184, with potent antitumor activity and a distinct mechanism. ACS Chem Biol 2013; 8: 2084-2094

113 Martínez-Díez M, Guillen-Navarro MJ, Pera B, Bouchet BP, MartínezLeal JF, Barasoain I, Cuevas C, Andreu JM, Garcıa-Fernandez LF, Díaz JF, Aviles P, Galmarini CM. PM060184, a new tubulin binding agent with potent antitumor activity including P-glycoprotein over-expressing tumors. Biochem Pharmacol 2014; 88: 291-302

114 Aviles P, Guillen MJ, Lopez-Casas PP, Sarno F, Cataluna O, Nunez P, Cuevas $C$, Hidalgo M. Low, frequent doses of PM060184 induce remarkable in vivo antitumor activity. Eur I Cancer 2014; 50: 23

115 Aviles PM, Guillen MJ, Dominguez JM, Munoz-Alonso J, Garcia-Fernandez LF, Garranzo M, Martinez V, Francesch A, Munt S, Galmarini CM, Cuevas C. MI130004, an antibody-drug conjugate including a novel payload of marine origin: Evidences of in vivo activity. Eur J Cancer 2014; 50: 164
116 Coello L, Reyes F, Martín MJ, Cuevas C, Fernandez R. Isolation and structures of pipecolidepsins A and B, cytotoxic cyclic depsipeptides from the Madagascan sponge Homophymia lamellosa. J Nat Prod 2014; 77: 298-303

117 Mayer AMS, Glaser KB, Cuevas C, Jacobs RS, Kem W, Little RD, McIntosh $J M$, Newman DJ, Potts BC, Shuster DE. The odyssey of marine pharmaceuticals: a current pipeline perspective. Trends Pharmacol Sci 2010; 31: $255-265$

118 Molina-Guijarro JM, Moneo V, Martinez-Leal JF, Cuevas C, Garcia-Fernandez LF, Galmarini CM. Pipecolidepsin A, Stellatolide A and Irvalec: New cyclodepsipeptides of marine origin with antitumor activity. Eur J Cancer 2014; 50: 24

119 Fenical W, Jensen PR, Palladino MA, Lam KS, Lloyd GK, Potts BC. Discovery and development of the anticancer agent salinosporamide A (NPI0052). Bioorg Med Chem 2009; 17: 2175-2180

120 Lechner A, Eustáquio AS, Gulder TA, Hafner M, Moore BS. Selective overproduction of the proteasome inhibitor salinosporamide A via precursor pathway regulation. Chem Biol 2011; 18: 1527-1536

121 Eustáquio AS, Nam SJ, Penn K, Lechner A, Wilson MC, Fenical W, Jensen $P R$, Moore BS. The discovery of salinosporamide K from the marine bacterium "Salinispora pacifica" by genome mining gives insight into pathway evolution. Chembiochem 2011; 12: 61-64

122 Nguyen H, Ma G, Gladysheva T, Fremgen T, Romo D. Bioinspired tota synthesis and human proteasome inhibitory activity of (-)-salinosporamide $\mathrm{A},(-)$-homosalinosporamide $\mathrm{A}$, and derivatives obtained via organonucleophile promoted bis-cyclizations. J Org Chem 2011; 76: $2-12$

123 Jensen PR, Chavarria KL, Fenical W, Moore BS, Ziemert N. Challenges and triumphs to genomics-based natural product discovery. J Ind Microbiol Biotechnol 2014; 41: 203-209

124 Goo KS, Tsuda M, Ulanova D. Salinispora arenicola from temperate marine sediments: new intra-species variations and atypical distribution of secondary metabolic genes. Ant van Leeuwen 2014; 105: 207-219

125 Hale KJ, Hummersone MC, Manaviazar S, Frigerio M. The chemistry and biology of the bryostatin antitumour macrolides. Nat Prod Rep 2002; 19: 413-453

126 Hale KJ, Manaviazar S. New approaches to the total synthesis of the bryostatin antitumor macrolides. Chem Asian J 2010; 5: 704-754

127 Lin H, Yao X, Yi Y, Li X, Wu H. Bryostatin 19: A new antineoplastic compound from Bugula neritina in South China sea. Zhongguo Haiyang Yaowu 1998; 17: 1-3

128 Lin H, Liu G, Yi Y, Yao X, Wu H. Studies on antineoplastic constituents from marine bryozoan Bugula neritina inhabiting South China sea: isolation and structural elucidation of a novel macrolide. Dier Junyi Daxue Xuebao 2004; 25: 473-478

129 Lopanik N, Gustafson KR, Lindquist N. Structure of bryostatin 20: a symbiont-produced chemical defense for larvae of the host bryozoan, Bugula neritina. J Nat Prod 2004; 67: 1412-1414

130 Yu HB, Yang F, Li YY, Gan JH, Jiao WH, Lin HW. Cytotoxic bryostatin derivatives from the South China Sea bryozoan Bugula neritina. J Nat Prod 2015; 78: 1169-1173

131 Keck GE, Poudel YB, Cummins TJ, Rudra A, Covel JA. Total synthesis of bryostatin 1. J Am Chem Soc 2011; 133: 744-747

132 Manaviazar S, Hale KJ. Total synthesis of bryostatin 1: a short route. Angew Chem Int Ed 2011; 50: 8786-8789

133 Trost BM, Yang H, Brindle CS, Dong G. Atom-economic and stereoselective syntheses of the ring A and B subunits of the bryostatins. Chemistry 2011; 17: 9777-9788

134 Trost BM, Yang H, Dong G. Total syntheses of bryostatins: synthesis of two ring-expanded bryostatin analogues and the development of a new-generation strategy to access the C $7-C 27$ fragment. Chemistry 2011; 17: 9789-9805

135 Trindade-Silva AE, Lim-Fong GE, Sharp KH, Haygood MG. Bryostatins: biological context and biotechnological prospects. Curr Opin Biotechnol 2010; 21: 834-842

136 Keck GE, Kraft MB, Truong AP, Li W, Sanchez CC, Kedei N, Lewin NE, Blumberg PM. Convergent assembly of highly potent analogues of bryostatin 1 via pyran annulation: Bryostatin look-alikes that mimic phorbol ester function. J Am Chem Soc 2008; 130: 6660-6661

137 Wender PA, Baryza JL, Brenner SE, DeChristopher BA, Loy BA, Schrier AJ Verma VA. Design, synthesis, and evaluation of potent bryostatin analogs that modulate PKC translocation selectivity. Proc Natl Acad Sci U S A 2011; 108: 6721-6726 
138 Wender PA, Reuber J. Function oriented synthesis: preparation and initial biological evaluation of new A-ring-modified bryologs. Tetrahedron 2011; 67: 9998-10005

139 Newman DJ. The bryostatins. In: Cragg GM, Kingston DGI, Newman DJ, editors. Anticancer agents from natural products, 2nd edition. Boca Raton, FL: Taylor and Francis; 2012: 199-218

140 Kedei N, Lewin NE, Géczy T, Selezneva J, Braun DC, Chen J, Herrmann MA, Heldman MR, Lim L, Mannan P, Garfield SH, Poudel YB, Cummins TJ, Rudra A, Blumberg PM, Keck GE. Biological profile of the less lipophilic and synthetically more accessible bryostatin 7 closely resembles that of bryostatin 1. ACS Chem Biol 2013; 8: 767-777

141 DeChristopher BA, Loy BA, Marsden MD, Schrier AJ, Zack JA, Wender PA. Designed, synthetically accessible bryostatin analogues potently induce activation of latent HIV reservoirs in vitro. Nat Chem 2012; 4: 705-710

142 Newman DJ. Bryostatin-from bryozoan to cancer drug. In: Gordon DP, Smith AM, Grant-Mackie JA, editors. Bryozoans in space and time. Wellington, NZ: NIWA; 1996: 9-17

143 Mori T, O'Keefe BR, Sowder RC 2nd, Bringans S, Gardella R, Berg S, Cochran P, Turpin JA, Buckheit RW jr., McMahon JB, Boyd MR. Isolation and characterization of Griffithsin, a novel HIV-inactivating protein, from the red alga Griffithsia sp. J Biol Chem 2005; 280: 9345-9353

144 Ziótkowska NE, Shenoy SR, O'Keefe BR, Wlodawer A. Crystallographic studies of the complexes of antiviral protein griffithsin with glucose and N-acetylglucosamine. Protein Sci 2007; 16: 1485-1489

145 O'Keefe BR, Vojdani F, Buffa V, Shattock RJ, Montefiori DC, Bakke J, Mirsalis J, d'Andrea AL, Hume SD, Bratcher B, Saucedo CJ, McMahon JB, Pogue GP, Palmer KE. Scaleable manufacture of HIV-1 entry inhibitor griffithsin and validation of its safety and efficacy as a topical microbicide component. Proc Natl Acad Sci U S A 2009; 106: 6099-6104

146 Takebe Y, Saucedo CJ, Lund G, Uenishi R, Hase S, Tsuchiura T, Kneteman $N$, Ramessar K, Tyrrell DLJ, Shirakura M, Wakita T, McMahon JB, O'Keefe $B R$. Antiviral lectins from red and blue-green algae show potent in vitro and in vivo activity against hepatitis C virus. PLoS One 2013; 8: e64449

147 Barton C, Kouokam JC, Lasnik AB, Foreman O, Cambon A, Brock G, Montefiori DC, Vojdani F, McCormick AA, O'Keefe BR, Palmer KE. Activity of and effect of subcutaneous treatment with the broad-spectrum antiviral lectin griffithsin in two laboratory rodent models. Antimicrob Agents Chemother 2014; 58: 120-127

148 Dixit RB, Suseela MR. Cyanobacteria: potential candidates for drug discovery. Ant van Leeuwen 2013; 103: 947-961

149 Winnikoff JR, Glukhov E, Watrous J, Dorrestein PC, Gerwick WH. Quantitative molecular networking to profile marine cyanobacterial metabolomes. J Antibiot (Tokyo) 2014; 67: 105-112

150 Kleigrewe K, Almaliti J, Tian IY, Kinnel RB, Korobeynikov A, Monroe EA, Duggan BM, Di Marzo V, Sherman DH, Dorrestein PC, Gerwick L, Gerwick WH. Combining Mass Spectrometric Metabolic Profiling with Genomic Analysis: A Powerful Approach for Discovering Natural Products from Cyanobacteria. J Nat Prod 2015; 78: 1671-1682

$151 \mathrm{Ng} \mathrm{TB}$, Cheung RC, Wong JH, Bekhit AA, Bekhit Ael-D. Antibacterial products of marine organisms. Appl Microbiol Biotechnol 2015; 99: 4145-4173

152 Gerwick WH, Moore BS. Lessons from the past and charting the future of marine natural products drug discovery and chemical biology. Chem Biol 2012; 19: 85-98 